\title{
An overview of siderophores for iron acquisition in microorganisms living in the extreme
}

\section{Authors: Luis O. De Serrano, Anne K. Camper, \& Abigail M. Richards.}

NOTICE: The final publication is available at Springer via http://dx.doi.org/10.1007/ s10534-016-9949-X.

De Serrano LO, Camper AK, Richards AM "An overview of siderophores for iron acquisition in microorganisms living in the extreme," Biometals,2016 Aug;29(4):551-71.

Made available through Montana State University's ScholarWorks

scholarworks. montana.edu 


\title{
An overview of siderophores for iron acquisition in microorganisms living in the extreme
}

Luis O. De Serrano · Anne K. Camper · Abigail M. Richards

L. O. De Serrano (\&) · A. K. Camper

Department of Microbiology \& Immunology, Montana State University, Bozeman, MT 59717, USA

A. K. Camper

Department of Civil \& Environmental Engineering, Montana State University, Bozeman, MT 59717, USA

A. M. Richards

Department of Chemical \& Biological Engineering, Montana State University, Bozeman, MT 59717, USA

L. O. De Serrano · A. K. Camper · A. M. Richards Center for Biofilm Engineering, Montana State University, Bozeman, MT 59717, USA

\begin{abstract}
Siderophores are iron-chelating molecules produced by microbes when intracellular iron con-centrations are low. Low iron triggers a cascade of gene activation, allowing the cell to survive due to the synthesis of important proteins involved in side-rophore synthesis and transport. Generally, siderophores are classified by their functional groups as catecholates, hydroxamates and hydroxycarboxylates. Although other chemical structural modifications and functional groups can be found. The functional groups participate in the iron-chelating process when the ferri-siderophore complex is formed. Classified as acidophiles, alkaliphiles, halophiles, thermophiles, psychrophiles, piezophiles, extremophiles have particular iron requirements depending on the environ-mental conditions in where they grow. Most of the work done in siderophore production by extremo-philes is based in siderophore concentration and/or genomic studies determining the presence of side-rophore synthesis and transport genes. Siderophores produced by extremophiles are not well known and more work needs to be done to elucidate chemical structures and their role in microorganism survival and metal cycling in extreme environments.
\end{abstract}

\section{Keywords}

Iron acquisition $\cdot$ Siderophores $\cdot$ Siderophore synthesis and transport $\cdot$ Extremophiles

\section{Introduction}

Almost all microorganisms require iron for their cellular processes. Iron is involved in several pivotal cellular processes, including amino acid synthesis, oxygen transport, respiration, nitrogen fixation, methanogenesis, the citric acid cycle, photosynthesis and DNA biosynthesis. Iron concentrations in the extracellular environment are low $\left(10^{-18} \mathrm{M}\right)$ and limited by the insolubility of $\mathrm{Fe}(\mathrm{OH}) 3$. Microorganisms require micromolar concentrations of iron, but many environments, such surface ocean water, has concentrations ranging from 0.01 to $2 \mathrm{nM}$ (Luther and $\mathrm{Wu}$ 1997). Iron can be present in its ferric $\left(\mathrm{Fe}^{+3}\right)$ or ferrous $\left(\mathrm{Fe}^{+2}\right)$ forms. The redox potential of the latter is suitable as a protein catalytic center (Krewulak and Vogel 2008). For pathogenic microorganisms, iron 
availability is even lower due to mammalian host proteins (heme, lactoferrin, transferrin and ferritin) that sequester iron from the plasma (Krewulak and Vogel 2008). In overcome the scarcity of iron, many organisms have developed different mechanisms for iron capture: siderophores, hemophores, ferric binding proteins and transferrin/lactoferrin receptors (Sandy and Butler 2009). These molecules and proteins work together to increase the iron acquisition capabilities of the microbial cell. Siderophores are small molecules of approximately 500-1200 Da in size which specifically bind ferric iron with high affinity, are excreted into the environment, thus increasing the bioavailability of this otherwise insoluble nutrient.

The production of siderophores by disease causing microbes and many terrestrial microorganisms is well studied. The prevalence of siderophore production within extreme environments or by microbes classified as "extremophiles" is less so. This review will briefly summarize iron acquisition and siderophores produced by both terrestrial and pathogenic microbes. A discussion of the siderophores synthesized by extremophiles (acidophiles, alkaliphiles, thermo/hyperthermophiles, psychrophiles, piezophiles etc.) or siderophores produced by microbes tolerant of extreme conditions ( $\mathrm{pH}$, salinity, temperature, pressure) will follow.

\section{Acquisition and transport of ferric iron siderophore-mediated iron acquisition}

The active transport of ferric iron across the cell (Fig. 1; Crosa et al. 2004), is due to the use of porins for the high molecular weight ferric-siderophore complex, and requires different transport proteins and receptors. Outer membrane receptors are responsible for of recognizing iron-bound siderophores outside the cell, and include FhuA, FecA and FepA found in Escherichia coli (Ferguson et al. 1998, 2000, 2002, 2001; Yue et al. 2003), and BtuB, FpvA and FptA found in Pseudomonas aeruginosa (Cobessi et al. 2005a, b; Cornelis et al. 2009). Their structure is composed of $\beta$-barrel and cork domains, (Krewulak and Vogel 2008) the former of which spans the membrane and helps to form a hollow space where the iron-sidrophore complex passes through to the periplasm, while the cork domain binds the ironsiderophore complex and brings it into the $\beta$-barrel.
The outer membrane of gram-negative cells does not have a proton motive force that will provide the energy required for active transport, so that role is performed by the TonB, ExbB and ExbD proteins. The amino- and carboxy-terminal domains provide the energy required to transport ferri-siderophores across the outer membrane. The remaining proteins, ExbB and ExbD, assist TonB in energy transduction.

In the periplasm there are periplasmic siderophore binding proteins (PSBP) to transport ferric siderophores across the cytoplasmic membrane. The word siderophore is included in this term because there are about eight different clusters of periplasmic binding proteins (Crosa et al. 2004; Krewulak and Vogel 2008) that bind oligosaccharides, sugars, phosphate, amino acids (polar and non-polar), organic polyanions, peptides, iron complexes and other metals. FhuD, FbpA and BtuF are the most studied PSBPs and are associated with iron uptake metabolism and transport. Specific group-coordinating PSBPs will shuttle their corresponding siderophore through the periplasm until the PSBP-siderophore-iron complex reaches transporters on the cytoplasm.

The transporters are a class of ATP-binding cassettes (ABC transporter proteins). The best example known today is the FhuBDC. The complex couples ATP hydrolysis to transport the iron-siderophore through the cytoplasmic membrane into the cytoplasm. FhuD is the PSBP for hydroxamate siderophores, and well-studied due to its complete structure elucidation. FhuB and FhuC are ABC transporter proteins. Due to their transmembrane domains, FhuBC form channels where the siderophore-iron complex passes through. It also has two nucleotide binding domains that hydrolyze ATP. In brief, FhuD transfers the siderophore-iron complex to FhuB, the complex is translocated to the channel; in the meantime FhuC hydrolyses ATP. Finally the siderophore-iron complex is dissociated by an electron transfer to ferric iron $\left(\mathrm{Fe}^{+3}\right)$, converting it to ferrous iron $\left(\mathrm{Fe}^{+2}\right)$.

\section{Ferrous iron uptake}

The mechanism of ferrous iron intake, contrary to ferric iron acquisition, is not well understood. Ferrous iron solubility is higher at neutral $\mathrm{pH}$ compared to ferric iron and this facilitates transport across the membrane. Ferrous iron concentration is higher under anaerobic or reducing conditions. Two different systems for ferrous 


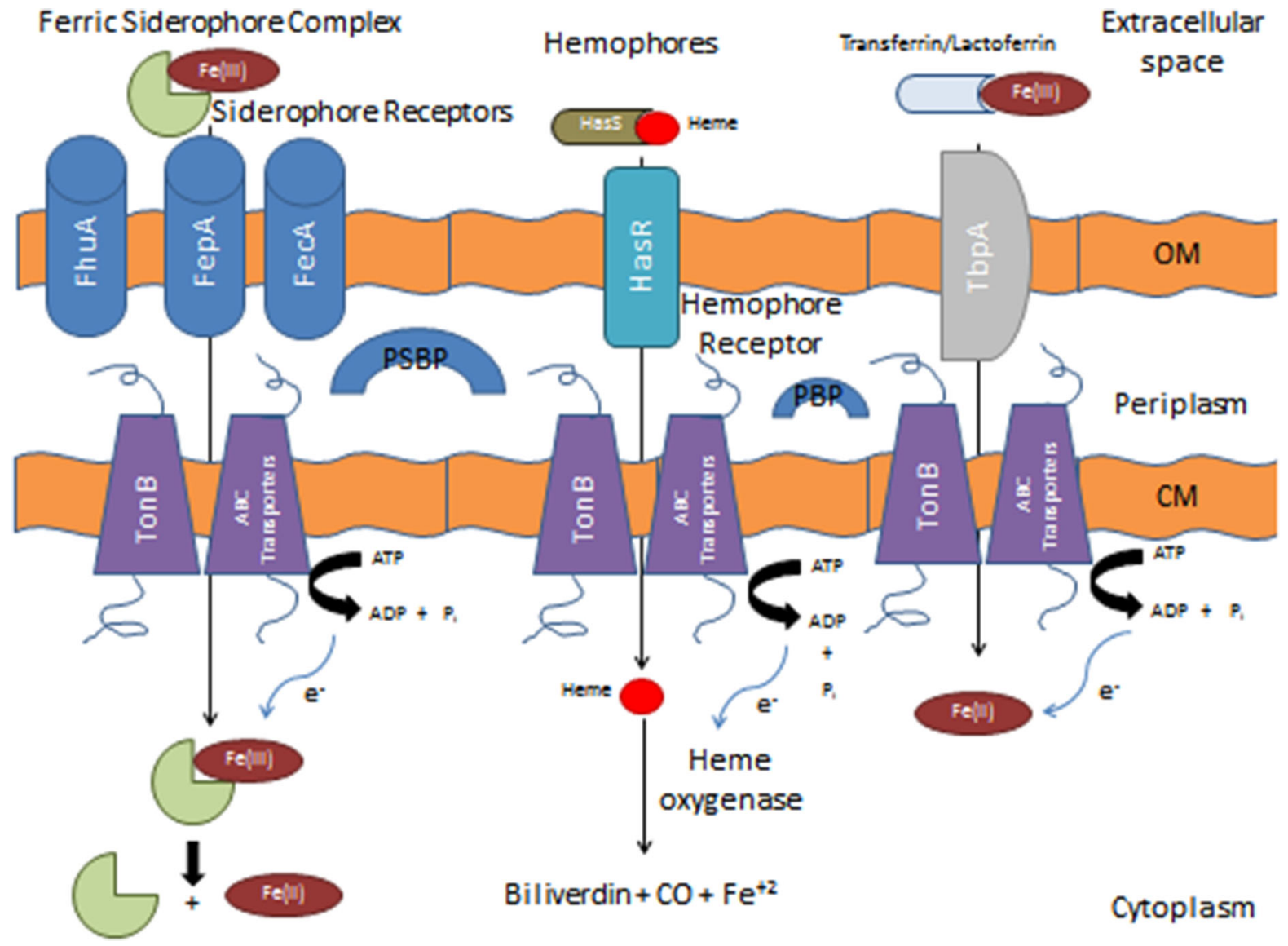

Fig. 1 Iron acquisition in a gram-negative bacterial cell. $O M$ outer membrane, $C M$ cytoplasmic membrane, $P S B P$ periplasmic siderophore binding protein, $P B P$ periplasmic binding

iron uptake have been described: Feo and Sit (Carpenter and Payne 2014; Hantke 1987; Weaver et al. 2013). The Feo and Sit operon systems, co-repressed by Fur and iron (II), code for membrane-bound and cytoplasmic proteins that participate in the active transport of ferrous iron. Both ferrous uptake systems described are required for pathogenicity (Boyer et al. 2002; Fisher et al. 2009; Tsolis et al. 1996).

\section{Regulatory characteristics of siderophore production}

Fur-mediated regulation of siderophore production

Bacteria utilize siderophores to obtain the iron necessary for their survival. However, iron is toxic and must be tightly regulated within the cell. The most studied iron protein. ABC transporter includes proteins ExbB and ExbD and help in ATP hydrolysis to obtain energy for active transport. Adapted from Krewulak and Vogel (2008)

regulation system is fur (for ferric uptake regulation) (Hantke 2004; Lorenzo et al. 2004). Figure 2 presents a general description of the regulatory system at high and low iron concentration, inducing transcription of siderophore synthesis proteins and transportation into the extracellular space for iron scavenging. At high iron concentrations, the Fur protein undergoes conformational changes, attaches to the fur box to hinder the transcription of siderophore genes. At low iron concentrations, no iron (II) is bounded to the Fur protein, allowing the transcription of siderophore-related genes.

Siderophore regulation by quorum sensing

In addition to iron-dependent regulation, some bacteria regulate siderophore production by means of quorum sensing. Quorum sensing occurs in a cell densitydependent manner and helps regulate different functions 
Fig. 2 Siderophoremediated iron acquisition system regulated by the Fur protein. Adapted from Crosa et al. (2004)
High Iron Concentration

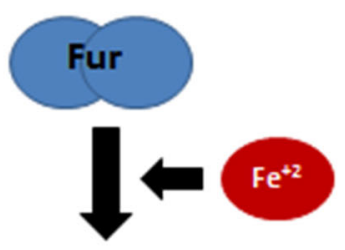

$\mathrm{Fe}^{+2}$

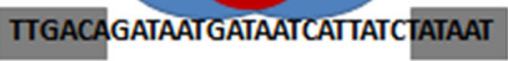

$-35$

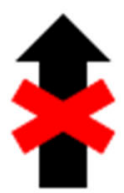

RNA Polymerase

$-10$
Low Iron Concentration

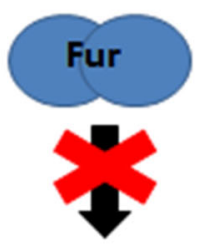

RNA Polymerase

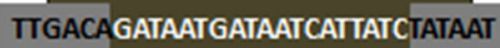

$-35$

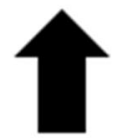

RNA Polymerase in the cell, triggering the corresponding phenotype response. Different physiological conditions are affected by quorum sensing, including: biofilm formation (Christiaen et al. 2014; Kadirvel et al. 2014), swarming motility (Vasavi et al. 2014), bioluminescence (Packiavathy et al. 2013), antibiotic production and resistance (Fineran et al. 2005), production of pharmaceuticals (Raina et al. 2012) and toxins (Tal-Gan et al. 2013).

Due to some contradictory findings, it is unclear how quorum sensing regulates siderophore synthesis, therefore more research efforts need to address this lack of information. Siderophore production is significantly impacted by quorum sensing in some bacteria, especially pathogens. Stintzi et al. (1998) described that lasR mutants were affected in siderophore production, specifically pyoverdine in $P$. aeruginosa. Another siderophore produced by $P$. aeruginosa is pyochelin and it was not affected by the deficiency in the autoinducer production. In contrast, Burkholderia cepacia quorum sensing mutants tend to overproduce the siderophore ornibactin (Lewenza et al. 1999). Complementation restored siderophore production to original levels.

\section{Siderophore coordination groups}

Siderophore classification is based on certain functional groups that are involved in ferric iron coordination. Those groups include catechols, as in enterobactins; hydroxamates, as in desferrioxamines; and $\alpha$-hydroxycarboxilates, as in achromobactins (Fig. 3). These functional groups are donors of three OO' in order that six oxygen atoms coordinate the ferric iron. Mixed functional group siderophores, such as the siderophore aerobactin which contains two hydroxamates and one hydroxycarboxilic acid group, are also observed. A quintessential representative of a catecholate siderophore is enterobactin (Fig. 4) and is produced by $E$. coli and other enteric pathogens (Gehring et al. 1997). Salmochelin is a glucosylated form of enterobactin produced by Salmonella enterica and uropathogenic E. coli (Bister et al. 2004).

The best known example of hydroxamate siderophores are the ferrioxamines (so-called desferrioxamines when no ferric iron is coordinated). Their structural composition is alternating units of succinic<smiles>Oc1ccccc1O</smiles>

(a)<smiles>CN(O)C(=O)O</smiles>

(b)<smiles>CC(=O)C(C)O</smiles>

(c)
Fig. 3 Siderophore functional groups: catechols (a), hydroxamates (b) and $\alpha$-hydroxycarboxylates (c). Note the $\mathrm{OO}^{\prime}$ groups provided by the hydroxyl and carbonyl moieties. Adapted from Krewulak and Vogel (2008) 


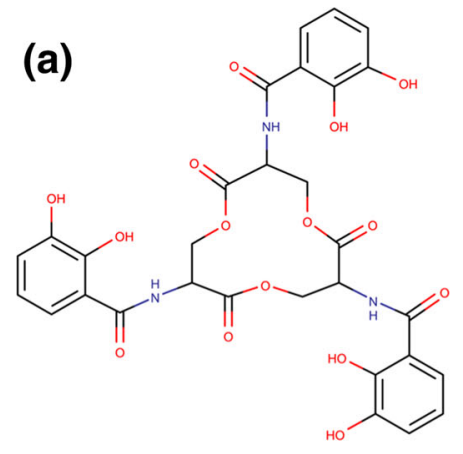

(d)

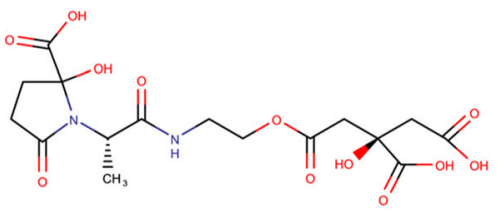

(f)

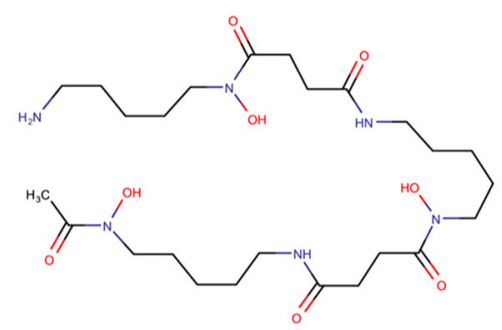

Fig. 4 Enterobactin (catechol, a), desferrioxamine E (cyclic hydroxamate, b), achromobactin (hydroxycarboxylate, c), vibrioferrin (hydroxycarboxylate, d), citrate (e),

acid and monohydroxylated diamine, either N-hydroxycadaverine or N-hydroxyputrescine. Some desferrioxamines are in cyclic form, such as desferrioxamine E (Fig. 4) (Ejje et al. 2013; Konetschny-Rapp et al. 1992), while others are linear, such as desferrioxamines B (Fig. 4) (Ejje et al. 2013; Martinez et al. 2001) and G (Bergeron et al. 1992; Ejje et al. 2013). More recently, di- and tri-hydroxamic acid siderophores (putrebactins, scabichelins and turgichelins) have been characterized from Shewanella putrefaciens, Streptomyces antibioticus, Streptomyces scabies and Streptomyces turgidiscabies (Kodani et al. 2013; Soe and Codd 2014).

Achromobactin is produced by Pseudomonas syringae pv. syringae (Berti and Thomas 2009) and is a tris- $\alpha$-hydroxycarboxylate siderophore (Fig. 4). A second siderophore that falls in this group is vibrioferrin (Fig. 4), categorized as a bis- $\alpha$-hydroxycarboxilic siderophore (Amin et al. 2009; Harris et al. 2007). Some siderophores use only citrate to coordinate ferric (c)

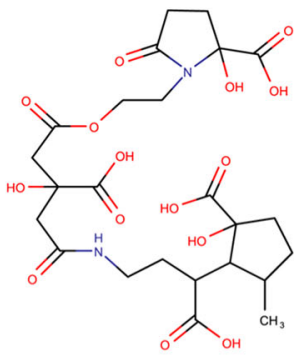

(e)<smiles>O=C(O)CC(O)(CC(=O)O)C(=O)O</smiles>

(g)

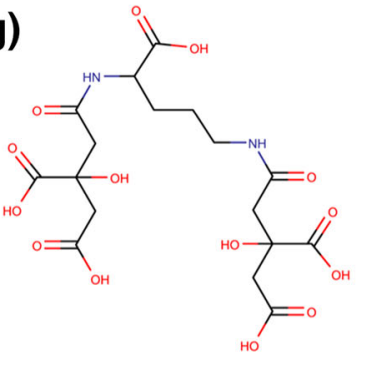

desferrioxamine B (linear, hydroxamate, f) and staphyloferrin A (hydroxycarboxylate, g) structures. Adapted from Sandy and Butler (2009)

iron (Fig. 4). Rhizoferrin's two coordinating groups are donated from two citrates as well as those from staphyloferrin A (Fig. 4) (Cotton et al. 2009; Drechsel et al. 1991; Harris et al. 2007; Meiwes et al. 1990).

There are many siderophores that contain mixed coordinating functional groups. This group of siderophores is composed by bidentate ligand and also amphiphilic siderophores. Examples are aerobactins, amphibactins, ochrobactins, marinobactins, aquachelins, lystabactins, rhodobactins and amychelins among others (Fig. 5; Dhungana et al. 2007; Neilands 1995; Seyedsayamdost et al. 2011; Zane and Butler 2013).

\section{Siderophores produced by extremophiles}

Microorganisms living in extreme environmental conditions (high acidities, alkalinities, temperatures, or barometric pressures; the ability to grow in organic solvents; or low temperatures) are known as 

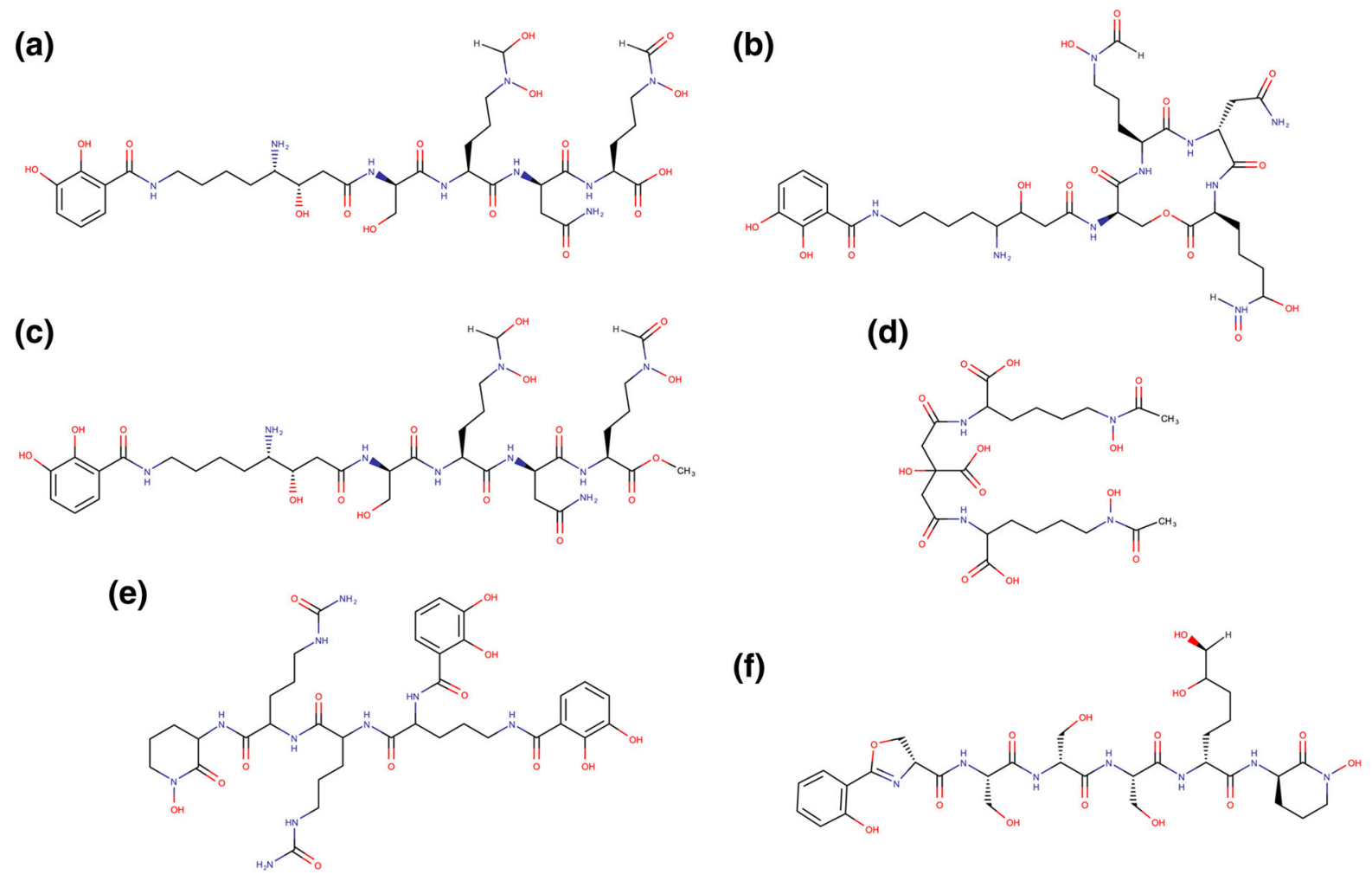

Fig. 5 Some mixed functional groups siderophores: lystabactins (a-c), aerobactin (d), rhodobactin (e) and amychelin (f). Adapted from Sandy and Butler (2009), Seyedsayamdost et al. (2011) and Dhungana et al. (2007)

extremophiles. It is important to make the distinction between tolerant and extremophile microorganisms. Certain microbes isolated in non-extreme environments, can grow in specific extreme conditions [like high pressure, (Olsson-Francis et al. 2010) or high temperature and in the presence of organic solvents (Tang et al. 2009)], however surpassing their tolerance level could cause death of the microbe (Huidrom et al. 2011).

Microorganisms classified as acidophiles (living at $\mathrm{pH}<4$ ), alkaliphiles ( $\mathrm{pH}>8$ ), thermophiles (from about 40 to $110{ }^{\circ} \mathrm{C}$ ), piezophiles (high barometric pressures) and psychrophiles $\left(-20-10^{\circ} \mathrm{C}\right.$ ) depending on their extreme environment. Although these physiological classifications exist, it is important to note that a species could have two or more physiological requirements (for example: halophile and thermophile, alkaliphile and halophile, or piezophile and psychrophile). Extremophiles possess the required cellular machinery to survive such conditions (Calo et al. 2010; Doukyu and Ogino 2010; Eichler 2003; Georlette et al. 2003; Jarrell et al. 2011; Kogej et al. 2006; Scandurra et al. 1998).
Scarce information is available for siderophoremediated iron acquisition in extremophiles (Ye et al. 2004) but some physiological groups (halophiles and thermophiles) have more available structural information than others (alkaliphiles, acidophiles, piezophiles and psychrophiles). Microbial Fe(III) reduction has been described in diverse conditions, including acidic (Kusel et al. 1999), alkaliphilic (McMillan et al. 2010; Ye et al. 2004), thermophilic (Liu et al. 1997; Zhang et al. 2013; Zhou et al. 2001), psychrophilic (Zhang et al. 1999) and halophilic (Emmerich et al. 2012; Handley and Lloyd 2013) environments. Depending on the metabolic requirements and environmental conditions, ferric iron could be an essential micronutrient (although in extreme acidic conditions ferrous, and not ferric, iron is available).

Siderophores produced by acidophiles

Iron bioavailability in acidic environments is high when comparing to neutral $\mathrm{pH}$ environments. At such environmental situations soluble ferric iron is at a 
concentration of 0.1 M (at pH 2) (Quatrini et al. 2007). In neutrophilic environments the ferric iron bioavailable concentration is at $10^{-18} \mathrm{M}$. Ferrous iron predominates in acidic conditions presenting risk for cellular toxicity due to the production of radicals. Therefore, acidic environments present two main challenges to microorganisms living in such conditions: (1) cellular iron homeostasis needs to be maintained to avoid toxic levels and (2) iron utilized as energy source and an important micronutrient for optimal cellular metabolic functions (Quatrini et al. 2007) regulated.

Microbial iron oxidation for the production of cellular energy tend to occurs frequently in acidic environments and several studies described the different mechanisms of iron acquisition and management of selected acidophiles (Bonnefoy and Holmes 2012). Osorio et al. took a bioinformatics approach for the study of iron transport proteins in three acidithiobacilli (Osorio et al. 2008). It was found that Acidithiobacillus ferrooxidans, Acidithiobacillus thiooxidans and Acidithiobacillus caldus possess the corresponding genetic information to oxidize ferrous iron. The A. ferrooxidans Fur box regulator was studied by another group of scientists and it was determined to have the ability to complement $\Delta f u r$ E.coli (Quatrini et al. 2005). Other bioinformatic studies present valuable information regarding iron homeostasis in Ferroplasma acidarmanus (Potrykus et al. 2011). Genes responsible for iron metabolism were up-regulated when $F$. acidarmanus was grown in iron poor conditions.

There is some genomic computational analysis information available on siderophore-mediated iron acquisition (Osorio et al. 2008; Potrykus et al. 2011). A. ferrooxidans and A. thiooxidans have the genetic capability for citrate (a siderophore) production, a citrate efflux pump and a TonB-dependent Fe(III)dicitrate transport systems (Osorio et al. 2008). Potrykus et al. (2011) determined that $F$. acidarmanus carries a gene for siderophore synthesis and internalization (ZP_05571308 and ZP_05571695, respectively). However, the type of siderophore produced by $F$. acidarmanus was not determined, leaving an open question regarding the structure of the siderophore produced.

Phylogenetic and diversity studies have been performed on acidic soil environments due to plant growth-promotion capabilities of secondary metabolite production of rhizobia. The studies focused on siderophore production and other growth-promoting metabolites produced by acidophilic rhizobacteria like Bacillus, but no structural characterization of the siderophore was performed (Yadav et al. 2011). In that study, researchers found that most of the isolates produced siderophores ( 31 out of 49 isolates). Similar results were obtained by studies done by Karagoz et al. (2012). The isolates were related to Pseudomonas putida (7), P. fluorescens (2), Rhizobium radiobacter (1), P. syringae (1) and Bacillus atrophaeus (1). An earlier report by Verma et al. measured siderophore production activity in acidic soil isolates related to $P$. fluorescens (Verma et al. 2007). No structural studies were carried on in order to characterize the siderophore(s) produced by the isolates, but it is likely that pyoverdine (produced by Pseudomonas species) is a candidate (Kalinowski et al. 2006).

Siderophores produced by alkaliphiles

Alkaliphilic microorganisms are capable of growth and reproduction at high $\mathrm{pH}$ environments, typically $>8$. At such environmental conditions, iron exists in its ferric form $\left(\mathrm{Fe}^{+3}\right)$, reacting with oxygen to produce $\mathrm{Fe}(\mathrm{OH})_{3}$ and reducing its bioavailability. Alkaliphiles must overcome this physiological problem to survive, making siderophore-mediated iron acquisition a critical physiological step (McMillan et al. 2010; Sarethy et al. 2011). Several studies have examined alkaliphiles isolated from different environments that foster lower solubility and bioavailability to determine their physiological requirements (carbon and energy sources) and their possible utilization of certain metals (Blum et al. 1998; Luque-Almagro et al. 2005a, b; Wood and Kelly 1991; Ye et al. 2004).

Iron uptake by complexation with chelators has been studied previously in alkaline, anaerobic conditions (Ye et al. 2004). Additional strategies selected alkaliphiles use to obtain iron employ the interaction with cyanide (Luque-Almagro et al. 2005a, b, 2011). In these reports, researchers described the physiological characteristics of Pseudomonas pseudoalcaligenes CECT5344, especially its biodegradation potential by the bacterial utilization of ferrocyanide. The microorganism was able to synthesize siderophores but no chemical characterizations were performed. Other microorganisms, like Streptomyces, produce 
respiratory inhibitors with iron-chelating properties (Pick 2004). It was demonstrated in the report that the iron-bound antimycin A was utilized by the halotolerant alga, Dunaniella salina, as a possible ironacquisition pathway. Although researchers do not classify antimycin A as a siderophore, its chemical structure resembles that of enterobactin (Fig. 6). These reports demonstrate the capacity of microorganisms to utilize xenosiderophores, or siderophores produced by other microorganisms. In another study by Gascoyne and co-workers, bacterial isolates were obtained from different sample types including chalk soils, cement work wastes, alkaline soils and soda lakes (Gascoyne et al. 1991a, b). Researchers demonstrated that isolates were capable of obtaining iron and gallium by a siderophore-mediated mechanisms. Assay-mediated structural characterization (Arnow and Atkin assays) confirmed hydroxamic and catecholic acids type siderophores.

The studies presented here demonstrate the capabilities of alkaliphiles to thrive in low iron concentrations and their evolutionary responses to such environmental conditions that help them in their survival. However information regarding specific siderophore structures is scarce since most of the studies only determine siderophore presence via the chrome azurol sulfonate (CAS) assay. Future investigations of siderophores isolation and microbial ecology organisms in alkaline $\mathrm{pH}$ environments should focus not only on siderophore detection, but characterization, to better understand the specific mechanisms of iron uptake.

Siderophores produced at high-temperatures: thermophiles

High-temperature environments are widely spread on Earth, from thermal hot springs in Yellowstone National Park (Beam et al. 2014; Kozubal et al. 2013; Wu et al. 2013a) and Mexico (Brito et al. 2014), to deep-sea vents (Kaye et al. 2011; Pettit 2011), mines (Gounder et al. 2011) and volcanoes (Amaresan et al. 2014; Connell et al. 2009). A diverse population of organisms are found, representing the three branches of the tree of life: eukaryotes (Connell et al. 2009), archaea (Beam et al. 2014; Hedlund et al. 2013; Kozubal et al. 2013) and bacteria (Kaye et al. 2011; Temirov et al. 2003). New organisms and even phyla are being discovered, and their physiological characteristics determined, in such environmental conditions (Beam et al. 2014; Kozubal et al. 2013). For example, one possible mechanism for iron reduction in hightemperature is explained by methanogenic bacteria. In brief, ferric iron reduction decrease the reduction potential of the system allowing methanogenesis (which in return helps the methanogen to grow and<smiles>CCCCCC[C@@H]1C(=O)O[C@H](C)[C@H](OC(=O)CC(C)C)[C@@H](C)OC(=O)[C@H](NC(=O)c2cccc(NC=O)c2O)[C@@H](C)OC1=O</smiles>

\section{Enterobactin}

Antimycin A

Fig. 6 Enterobactin and antimycin A chemical structures 
in turn enhance ferric iron reduction) (Zhang et al. 2013).

Thermophiles are producers of a plethora of secondary metabolites like siderophores that could be key players for drug developments including antibiotics, antifungals, antibacterials and anticancer drugs (Pettit 2011), but little information about siderophore production and structural characterization is available (Temirov et al. 2003). Iron transport systems have been characterized in few thermophilic bacteria (Guerry et al. 1997). In some cases siderophore production assays are performed to characterize the isolates obtained, but no structural elucidation is attained (Sudek et al. 2009). The more common, siderophore-producing species present were Pseudomonas and Pseudoalteromonas, representing more than half of isolated microorganisms (41 and $26 \%$, respectively). The microorganisms withstood fluid temperatures up to $81{ }^{\circ} \mathrm{C}$ in basalt rock and iron mat samples in situ. Further in vitro studies of siderophore and metal chelation from volcanic rocks revealed the transfer of the iron and other metals from the rock matrix to the aqueous phase of glacial meltwater, increasing iron bioavailability (Bau et al. 2013). Therefore, it is not surprise to find metal oxidizing bacteria with siderophore-producing bacteria, creating a community where mutualism is the key for survival.
To the best of our knowledge, there are three reports that present the structural characterization of siderophores produced by thermophilic species. Machuca and co-workers purified and partially characterized a low-molecular mass component (530 Da) from the fungus Thermoascus aurantiacus grown at $48{ }^{\circ} \mathrm{C}$ and low-pH conditions (Machuca et al. 1999). X-ray fluorescence determined the presence of iron, calcium and magnesium in the purified metabolite samples, indicating potential metal chelation (main characteristic of siderophores). The following study investigated the siderophore production of the thermoresistant bacterium B. licheniformis VK21 (Temirov et al. 2003). The purified compound, $S_{\mathrm{VK} 21}$ (Fig. 7), was analyzed with NMR spectroscopy and its structure was determined to be 2,3-dihydroxybenzoylglycyl-threonine, which after comparison with bacillibactin, it was suggested to be a fragment of the latter. The final study elucidated the structure and<smiles>CC(C)C(NC(=O)CNC(=O)c1cccc(O)c1O)C(=O)O</smiles>

Fig. $7 \quad \mathrm{~S}_{\mathrm{VK} 21}$ siderophore produced by B. licheniformis VK21
Fig. 8 Fuscachelins produced by the thermophile T. fusca

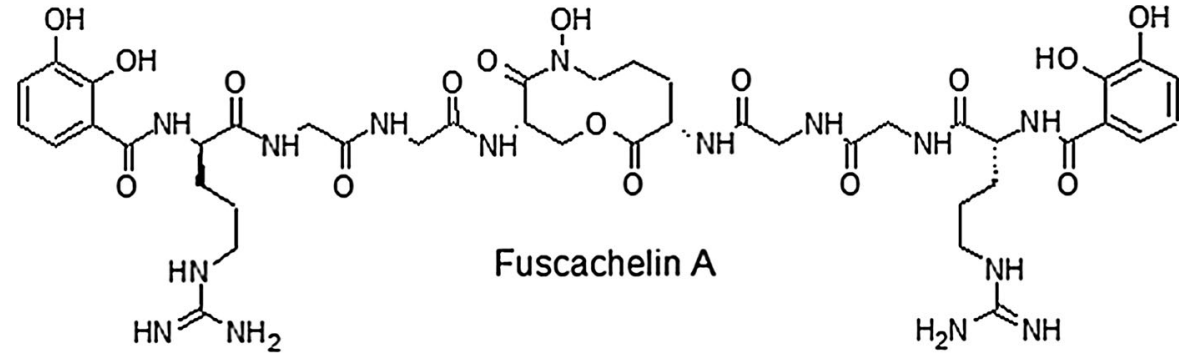<smiles>[R]C(=O)C(CCCN(O)C(=O)CCO)NC(=O)CNC(=O)CNC(=O)CNC(=O)CNC(=O)CNC(=O)C(CCCNC(=N)N)NC(=O)c1cccc(O)c1O</smiles> 
biosynthesis of fuscachelins (Fig. 8), produced by the moderate thermophile Thermobifida fusca, (Dimise et al. 2008). These few studies show that there is still more to investigate to unveil the relationship between secondary metabolites and important biogeochemical processes.

Siderophores produced by psychrophilic microorganisms

Low-temperature environments represent one of the most hostile living conditions. For some time they were thought to be inhabitable (Horowitz et al. 1972). An example of such extreme environmental conditions (average temperature of $-22{ }^{\circ} \mathrm{C}$ and winter temperatures as low as $-60{ }^{\circ} \mathrm{C}$ ) is the McMurdo Dry Valleys in Antarctica (Friedmann et al. 1987; Friedmann and Ocampo 1976; Siebert et al. 1996). In spite of the hostile conditions, living organisms' presence was confirmed and it was demonstrated that they thrived in those environments (Friedmann and Ocampo 1976). Even the production of siderophores was described in such environment (Siebert et al. 1996) suggesting the presence of iron acquisition systems. Iron acquisition studies have been done on psychrophilic microorganisms (e.g., Oleispira antarctica) based on genome sequencing (Kube et al. 2013). Siderophore biosynthesis genes were also described in the microorganism and the genes were expressed during iron-limiting conditions. No structural characterization of the particular siderophore was done.

Bioprospecting studies have been done in lowtemperature environments with the aim of isolating plant growth-promoting bacteria (Balcazar et al. 2015; Yadav et al. 2015a). In those studies siderophore production experiments were performed but no structural characterizations were done. Since isolates were related to Pseudomonas sp., and other species members of siderophore-producing phyla (Actinobacteria, Firmicutes, $\beta$-Proteobacteria and $\gamma$-Proteobacteria), this suggest that these microorganisms could produce pyoverdines, pyochelins, bacillibactins, yersiniabactins and aerobactins.

Another study presented the results for diversity and functional annotation of psychrotrophic bacteria (Yadav et al. 2015b). The samples were obtained from soil and water from a cold desert and generated 325 bacterial isolates. Siderophore producers were identified by the typical CAS assay revealing 29 strains. As in previous reports discussed here, no structural characterizations were made. However, siderophore producers were related to Bacillus, Sanguibacter, Arthrobacter and other species for which siderophore structures are known (e.g., bacillibactin, sanguibactin, pyoverdine and pyochelin).

Studies of single species siderophore production are found in literature. One report characterized a bacterium, Pseudomonas sp. PGERs17 (MTCC 9000), isolated from the northern Indian Himalayas (Mishra et al. 2008). Siderophore production was confirmed by CAS assay at as low as $4{ }^{\circ} \mathrm{C}$, but higher siderophore production values were recorded at room temperature. No structural characterization of the siderophores produced was achieved, suggesting only pyoverdines and pyochelins as potential siderophore candidates in this microorganism. Ren et al. studied the bacterium Bacillus sp. PZ-1 (Ren et al. 2015). Siderophore production was confirmed but no structural characterization studies were performed.

The lack of information regarding structure of siderophores may be due to the difficulty to grow psychrophilic microorganisms. But the presence of iron acquisition systems and confirmation of siderophore production genes must be the motivation to engage in such studies to increase important scientific knowledge.

\section{Siderophores produced by halophiles}

The halophilic environments are those found in the oceans, salterns, desserts and soda (hypersaline) lakes and the microbial richness and diversity that thrives in them has been described (Bamforth 1984; Crognale et al. 2013; Emmerich et al. 2012; Ghozlan and Deif 2006; Pandit et al. 2015; Sunagawa et al. 2015). Halophilic microorganisms were found in the rhizosphere of halotolerant plants. Some bacterial species are unable to produce siderophores (Tipre et al. 2015) but others are capable of such mechanism (Sahay et al. 2012). In the latter report, researchers found that $21 \%$ of the hypersaline-lake isolated bacteria produce siderophores. No structural characterizations were made to elucidate the chemical structure of those siderophores produced. After 16S rRNA gene sequencing, the siderophore-producing microorganisms were related to bacterial species of which some siderophore structures are known (bacillibactin, marinobactins, amphibactins, sodachelins and halochelins) 
(Figueroa et al. 2015; Gledhill et al. 2004; Martinez and Butler 2007; Richards et al. 2006, 2007; Woo and Kim 2008). Other siderophore-producing microorganisms have been isolated from marsh water and soil samples but they failed to determine structure of siderophores (Malviya et al. 2014) or the presence of siderophore-mediated iron reduction (Rossello-Mora et al. 1995). Several published studies isolated siderophore producers from soda, or hypersaline, lakes (Figueroa et al. 2015, 2012; Ramadoss et al. 2013; Richards et al. 2006, 2007; Serrano Figueroa 2015). Chemical structure characterizations were performed by mass spectrometry and fatty acid methyl ester, and siderophores were classified as amphiphilic siderophores: sodachelins and halochelins (Fig. 9). Ramadoss and co-workers found that a total of three isolates

(a)

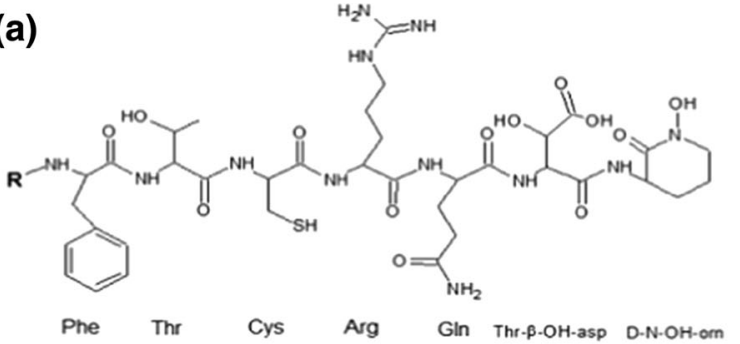

R:

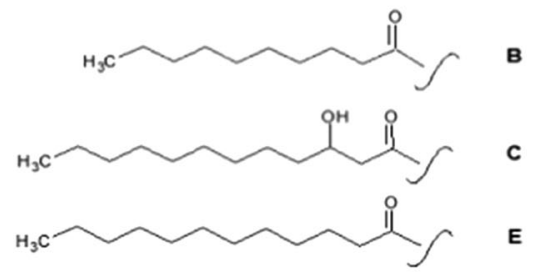

(SL3, SL32 and PU62), out of 84, from different hypersaline lakes of India produced siderophores. No chemical structure studies were done but phylogenetic analysis determined that SL3 was related to Halobacillus; SL32 to Bacillus pumilus; and PU62 to Bacillus halodenitrificans. Known siderophore production studies have been done on Halobacillus species to the best of our knowledge, however Bacillus species produce bacillibactin and we could infer that SL32 and PU62 may produce this siderophore. Additional reports described studies done for siderophore production with desert-isolated Kocuria turfanensis 2M4 and Bacillus licheniformis A2 bacteria (Goswami et al. 2014a, b) but in both reports no structural characterization was presented. Therefore, we suggest bacillibactin as the siderophore produced

(b)<smiles>CC(O)C(NC(=O)C(NC(=O)C(CO)NC(=O)C(CO)NC(=O)C1CCCN1C)C(=O)NC(CCCCNC(=N)N)C(=O)O)C(=O)NC(C(=O)O)C(=O)NC1CCCN1C</smiles>
Pro Arg Ser Thr. B.OH-asp Thr Ser O.N.OH-Om R:<smiles>CCCCCCCCCCCC(O)CC(=O)CC(=O)CCC(O)CC(=O)CF</smiles>

(c)<smiles>[2H]N[C@@H](C(=O)O)C(=O)N[C@@H](CCC(N)=O)C(=O)N[C@@H](CO)C(=O)N[C@@H](CCC(N)=O)C(=O)N[C@@H](CCCNO)C(=O)N[C@@H](CO)C(=O)N[C@@H](CCCNO)C(=O)O</smiles>

R:<smiles>CCCCCCCCCC(=O)CC</smiles><smiles>CCCCCCCCCCCCC(=O)CC(=O)CO</smiles><smiles>[B]CC(=O)CC(O)CCCCCCCCCC</smiles><smiles>CCCCCCC=CCCCCCC(=O)CC</smiles><smiles>CCCCCCC=CCCCC(=O)CCC</smiles><smiles>CCCCCCCCCCCCCCC(=O)CF</smiles>

Fig. 9 Halochelins (a, b) and sodachelins (c) produced by Halomonas sp. SL01 (a, b) and SL28 (c) 
by B. licheniformis A2 but further confirmation is needed. A more recent study confirmed the production of siderophores by another desert-isolated bacterium, B. cereus brm, however no chemical characterizations were performed (Vishal and Manuel 2015).

Iron acquisition studies have linked siderophores to proper and optimal cell development of halophiles (Anderson et al. 2011; Buyer et al. 1991; Hopkinson and Morel 2009; Wilhelm et al. 1998). Every year halophilic, siderophore-producing microorganisms are characterized by different research groups. Most of the siderophores produced by halophiles are classified as amphiphiles, meaning that the same molecule will have polar and non-polar properties. The polar headgroup is the iron binding site and it is attached to one or two of a series of fatty acids (Gauglitz et al. 2012; Ito and Butler 2005; Martin et al.
2006; Martinez et al. 2003, 2000; Owen et al. 2005). Figure 10 shows selected amphiphilic siderophore structures presenting the structural feature of $\alpha$ hydroxycarboxylic acid moiety, usually in the form of $\beta$-hydroxyaspartic acid or citric acid, conferring photochemical reactivity to the molecule as demonstrated previously (Barbeau et al. 2003, 2002; Butler et al. 2001; Butler and Theisen 2010).

As observed from the review in siderophoreproducing halophiles there is considerable information available about marine amphiphilic siderophores. However, little information is published regarding soda, hypersaline lakes and deserts. It is important to ensure the studies of these environments and look for secondary metabolite production, specifically siderophore production, and their relationship to iron acquisition and biogeochemical pathways. acquition and biogeochemical pathays. (a)

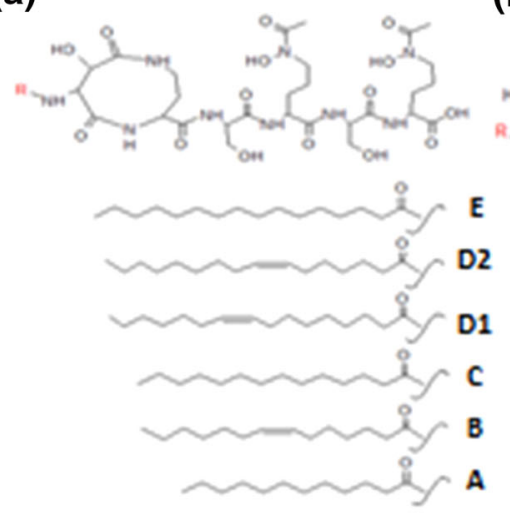

(d)
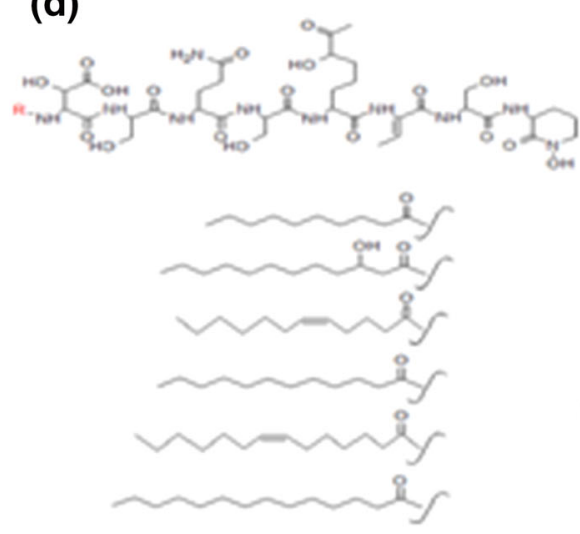

(b)

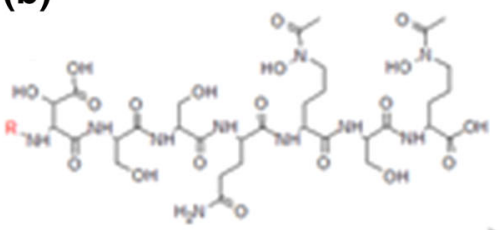

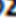

1

\section{con}

(1) (b) 
Siderophores produced by piezophiles

Piezophilic microorganisms (previously known as barophiles) grow and reproduce under high hydrostatic, or barometric, pressures (>1100 atm) (Deming and Colwell 1981). Typically that level of pressurization can be found in deep-sea environments (due to the pressure of the water column), under the basaltic sea floor (caused by both the water column and Earth's crust weight) and underground (subsurface) environments. In addition to hydrostatic pressure, most of the temperatures are below $4{ }^{\circ} \mathrm{C}$, and up to $400{ }^{\circ} \mathrm{C}$ nearby hydrothermal vents presenting a double challenge for microorganisms living in such conditions. It was thought by most scientists that life could not withstand the conditions present in these environments until independent studies by Certes and Regnard in 1884 stated the contrary. Posterior studies presented the evidence of life at depths greater than 10,000 m under sea level (Zobell and Morita 1957). Organisms living under the influence of high pressures evolved membranes with modified fatty acyl moieties in the phospholipids, making the membrane more fluid (Abe 2013). During the early times of deep-sea studies (piezobiology), a main objective was always present in the experimental design: to keep high hydrostatic pressures when sampling deep-sea water and sediments, avoiding decompression that may kill obligate piezophiles. Nowadays scientists have developed modern sampling systems that solve the decompression problem (Fang et al. 2010). With the assistance of robots and submarines sediments can be sampled and novel piezophilic species isolated to lead to an understanding of nutritional and physical requirements for their optimal cellular function (Bale et al. 1997; Nogi et al. 1998). In addition, with modern molecular biology techniques in non-cultivable approaches can be used to describe the microbial population living under the influence of high pressures (Fleming et al. 2013; Jorgensen et al. 2013; Wang et al. 2008).

Siderophore production and iron reduction are closely linked in microorganisms (Adams et al. 1992) by the effects of some physical and physicochemical conditions in the latter. Nutrient availability could also exert an effect on the viable cell count of these microorganisms (Wirsen and Molyneaux 1999). Microbial iron reduction and oxidation processes have been described in the literature. Model simulations proved that increasing the hydrostatic pressure on organisms causes a decrease of the energy yield of cellular reactions like oxygen reduction (Fang et al. 2010). In contrast, ferric iron reduction free energy increases as the pressure increases. Several studies have demonstrated that microorganisms belonging to the domains Bacteria and Archaea possess the required genetic machinery (Fleming et al. 2013; Jorgensen et al. 2013; Wang et al. 2008) and other investigations presented in vitro evidence of microbial iron reduction and oxidation (Picard et al. 2014; Wu et al. 2013b). Wang and co-workers isolated an ironreducing bacterium, Shewanella piezotolerans WP3 and determined by its genome sequencing the presence of $m$ tr-omc gene cluster involved in metal reduction in most Shewanella species. The group of Jorgensen and co-workers discovered that members of the deep sea archaeal group constitute up to $50 \%$ of the microbial population in certain sediment horizons. Also that group of investigators determined that there were significant variations in iron oxide and dissolved iron levels, implying redox reactions occurring in the microscopic community.

Not much information is available regarding siderophore-mediated iron acquisition and it is limited to simple, but significant, siderophore production experiments. The first evidence of potential siderophore production by genome analysis of the deep-sea bacterium, Pseudomonas sp. 10B238, confirmed the presence of non-ribosomal peptide synthetases genes (Pan and $\mathrm{Hu} 2015$ ). Additional genome studies have confirmed heterologous expression of hydrothermal deep-sea metagenomic DNA in E. coli, producing the siderophore avaroferrin (Fig. 11) and putrebactin (Fujita and Sakai 2014). The only direct siderophore isolation and structure identification was reported from the deep-sea microorganism Streptomyces olivaceus $\mathrm{FXJ} 8.012$ which produces tetroazolemycins A and B (Fig. 11; Liu et al. 2013).

In another study, arsenic-rich groundwater samples demonstrated the presence of siderophore-producing microorganisms (Sarkar et al. 2013). Siderophore structural studies were not done in this study but we can infer that ochrobactins (Martin et al. 2006) and alcaligin ( $\mathrm{Li}$ et al. 2013) may be the ones produced since bacterial species corresponding to these siderophores were isolated and identified through $16 \mathrm{~S}$ rRNA analysis. Since scarce siderophore structures were directly linked to siderophore production, there is 
Fig. 11 Additional siderophores produced by piezophilic microbes: avaroferrin (a), tetroazolemycin A (b) and tetroazolemycin B (c)<smiles>O=C1CCC(=O)N(O)CCCCCNC(=O)CCC(=O)N(O)CCCCN1</smiles>

(a) Avaroferrin<smiles>CC1[C@@H](CN2C(C)C3CSC(C2C)N(C[C@@H]2COC(c4ccccc4O)=N2)C3C)CS[C@H]1[C@H]1COC(c2ccccc2O)=N1</smiles>

(b) Tetroazolemycin $\mathrm{A}$<smiles>CC1[C@@H](CN2C(C)C3CSC(C2C)N(C[C@@H]2COC(c4ccccc4O)=N2)C3C)CS[C@H]1[C@H]1COC(c2ccccc2O)=N1</smiles>

(c) Tetroazolemycin B

a need to elucidate novel siderophore from piezophilic isolates. In this manner we may be able to link iron reduction and acquisition in these microorganisms with their siderophore production, and understand their role in deep-ocean and sediment biogeochemical processes.

\section{Concluding remarks}

Observing Fig. 10, we can conclude there might be certain levels of hydrophilicity or hydrophobicity in amphiphilic siderophores due to some molecular characteristics (length of fatty acyl moieties and headgroup). A clear example of this is the hydrophobicity of amphibactins (Gledhill et al. 2004; Vraspir et al. 2011), moanachelins (Gauglitz and Butler 2013) and ochrobactins (Gauglitz et al. 2012) contrasting to the hydrophilic lohichelins (Homann et al. 2009). This affects their extraction: amphibactins, moanachelins and ochrobactins are mainly obtained from cell pellet extracts, contrasting to the supernatant extracts that contain loihichelins. Marinobactins have been the most studied of the amphiphilic siderophores and have different degrees of hydrophobicity and hydrophilicity (Martinez and Butler 2007; Xu et al. 2002). Membrane partitioning studies were also done with ochrobactins giving similar results to those of the marinobactins (Martin et al. 2006). Aquachelins are quite hydrophilic especially aquachelins I and J isolated from Halomonas meridiana (Vraspir et al. 2011). Synechococcus sp. produces synechobactins (Fig. 10) which are related to the siderophore schizokinen (Ito and Butler 2005). Other siderophores can be taken up by another type of microorganism and then undergo changes in their structure. In Vibrio harveyi, enterobactin 
Fig. 12 Micelle and vesicle formation on amphiphilic siderophores due to critical micelle concentration $(\mathrm{cmc})$ and ferric iron chelation
Micelle-to-Vesicle Transition

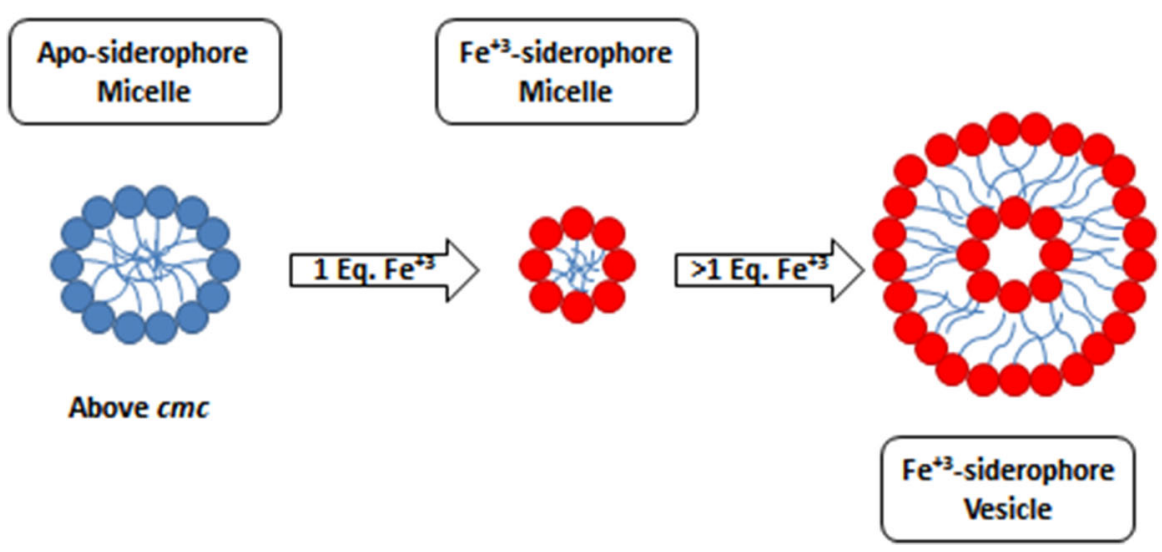

undergoes a chemical modification (addition of fatty acids moieties with different levels of saturation and hydroxylation) to transform it into an amphi-enterobactin (Zane et al. 2014). The relevance of amphiphilic siderophores chemical characteristics determine their extraction process, important in the study of new family members.

Another property of amphiphilic siderophores is the capacity of the molecules to self-assemble in micelles and vesicles upon iron coordination (Bednarova et al. 2008; Luo et al. 2002; Martinez et al. 2000; Owen et al. 2007, 2005, 2008). The science behind this phenomenon is based on the critical micelle concentration (cmc) of the amphiphile molecule. When the concentration of the amphiphilic siderophore is over the $\mathrm{cmc}$ and the siderophore is not bound to iron, micelle formation occurs. Adding ferric iron ( $\sim 1$ Eq.) to the solution causes micelle size reduction, but if the iron concentration increases ( $>1$ Eq.) a micelle-to-vesicle transition happens (Owen et al. 2005). A brief description of this process appears in Fig. 12.

Iron is ubiquitous in the environment and required by most living organisms. It is not bioavailable due to its poor solubility in water, but microorganisms have developed iron acquisition systems to overcome this problem. These acquisition systems help regulate a balanced iron concentration across the cell. Siderophore production and respective receptors and transport proteins are part of that system and help obtain iron from the extracellular environment in ironlimiting conditions. In general, three different functional groups (hydroxamates, catacholates and hydroxycarboxylates) are found in the siderophore molecule and assist in ferric iron coordination. Different structures are found in diverse environments including extreme environments. Extremophiles evolved to overcome the hostile conditions in such environments ensuring their survival and have developed mechanisms for iron acquisition. The physiological requirements for extremophiles are so complex and interweaved that a single extremophilic species could possess characteristics from two or more physiological groups (e.g., thermoacidophilic bacteria, haloalkaliphilic archaea etc.). Halophiles synthesize a variety of siderophores and some information is available regarding their structural composition. These structures contrast with the siderophore production and structural characterization studies from other physiological requirements groups (like piezophiles and acidophiles). Siderophores help maintain the equilibrium of iron in extreme environments providing physiological niches for extremophiles. More studies on extremophiles and siderophore production should be performed along characterization studies to elucidate siderophore chemical structures.

Acknowledgments Special thanks for the co-authors, Drs. Abigail M. Richards and Anne K. Camper, for their thoughtful insight and review of the manuscript. Thank you to members of the Camper Laboratory and graduate students and staff from the Center for Biofilm Engineering, Montana State University, Bozeman, USA.

\section{Compliance with ethical standards}

Conflict of Interest The authors declare that they have no conflict of interest. 


\section{References}

Abe F (2013) Dynamic structural changes in microbial membranes in response to high hydrostatic pressure analyzed using time-resolved fluorescence anisotropy measurement. Biophys Chem 183:3-8. doi:10.1016/j.bpc.2013.05.005

Adams JB, Palmer F, Staley JT (1992) Rock weathering in deserts-mobilization and concentration of ferric iron by microorganisms. Geomicrobiol J 10:99-114

Amaresan N, Kumar K, Sureshbabu K, Madhuri K (2014) Plant growth-promoting potential of bacteria isolated from active volcano sites of Barren Island, India. Lett Appl Microbiol 58:130-137. doi:10.1111/lam.12165

Amin S, Green D, Kupper F, Carrano C (2009) Vibrioferrin, an unusual marine siderophore: iron binding, photochemistry, and biological implications. Inorg Chem 48:11451-11458. doi:10.1021/ic9016883

Anderson I et al (2011) Novel insights into the diversity of catabolic metabolism from ten haloarchaeal genomes. Plos One 6:12. doi:10.1371/journal.pone.0020237

Balcazar W, Rondon J, Rengifo M, Ball MM, Melfo A, Gomez W, Yarzabal LA (2015) Bioprospecting glacial ice for plant growth promoting bacteria. Microbiol Res 177:1-7. doi:10.1016/j.micres.2015.05.001

Bale SJ, Goodman K, Rochelle PA, Marchesi JR, Fry JC, Weightman AJ, Parkes RJ (1997) Desulfovibrio profundus sp nov, a novel barophilic sulfate-reducing bacterium from deep sediment layers in the Japan Sea. Int J Syst Bacteriol 47:515-521

Bamforth SS (1984) Microbial distributions in Arizona Deserts and Woodlands. Soil Biol Biochem 16:133-137. doi:10. 1016/0038-0717(84)90103-2

Barbeau K, Zhang GP, Live DH, Butler A (2002) Petrobactin, a photoreactive siderophore produced by the oil-degrading marine bacterium marinobacter hydrocarbonoclasticus. J Am Chem Soc 124:378-379. doi:10.1021/ja0119088

Barbeau K, Rue EL, Trick CG, Bruland KT, Butler A (2003) Photochemical reactivity of siderophores produced by marine heterotrophic bacteria and cyanobacteria based on characteristic $\mathrm{Fe}(\mathrm{III})$ binding groups. Limnol Oceanogr 48:1069-1078

Bau M, Tepe N, Mohwinkel D (2013) Siderophore-promoted transfer of rare earth elements and iron from volcanic ash into glacial meltwater, river and ocean water Earth Planetary. Sci Lett 364:30-36. doi:10.1016/j.eps1.2013.01.002

Beam JP, Jay ZJ, Kozubal MA, Inskeep WP (2014) Niche specialization of novel Thaumarchaeota to oxic and hypoxic acidic geothermal springs of Yellowstone National Park. ISME J 8:938-951. doi:10.1038/ismej. 2013.193

Bednarova L, Brandel J, d'Hardemare A, Bednar J, Serratrice G, Pierre J (2008) Vesicles to concentrate iron in low-iron media: an attempt to mimic marine siderophores. Chem-A Eur J 14:3680-3686. doi:10.1002/chem.200701644

Bergeron RJ, Liu ZR, McManis JS, Wiegand J (1992) Structural alterations in desferrioxamine compatible with iron clearance in animals. J Med Chem 35:4739-4744. doi:10.1021/ jm00103a012
Berti AD, Thomas MG (2009) Analysis of achromobactin biosynthesis by pseudomonas syringae pv. syringae B728a. J Bacteriol 191:4594-4604. doi:10.1128/jb.00457-09

Bister B, Bischoff D, Nicholson GJ, Valdebenito M, Schneider K, Winkelmann G, Hantke K, Sussmuth RD (2004) The structure of salmochelins: C-glucosylated enterobactins of Salmonella enterica. Biometals 17:471-481. doi:10.1023/ B:BIOM.0000029432.69418.6a

Blum JS, Bindi AB, Buzzelli J, Stolz JF, Oremland RS (1998) Bacillus arsenicoselenatis, sp nov, and Bacillus selenitireducens, sp nov: two haloalkaliphiles from Mono Lake, California that respire oxyanions of selenium and arsenic. Arch Microbiol 171:19-30

Bonnefoy V, Holmes D (2012) Genomic insights into microbial iron oxidation and iron uptake strategies in extremely acidic environments. Environ Microbiol 14:1597-1611. doi:10.1111/j.1462-2920.2011.02626.x

Boyer E, Bergevin I, Malo D, Gros P, Cellier MFM (2002) Acquisition of $\mathrm{Mn}(\mathrm{II})$ in addition to $\mathrm{Fe}(\mathrm{II})$ is required for full virulence of Salmonella enterica serovar Typhimurium. Infect Immun 70:6032-6042. doi:10.1128/iai.70.11. 6032-6042.2002

Brito EMS et al (2014) Microbial diversity in Los Azufres geothermal field (Michoacan, Mexico) and isolation of representative sulfate and sulfur reducers. Extremophiles 18:385-398. doi:10.1007/s00792-013-0624-7

Butler A, Theisen RM (2010) Iron (III)-siderophore coordination chemistry: reactivity of marine siderophores. Coordin Chem Rev 254:288-296. doi:10.1016/j.ccr.2009.09.010

Butler A, Martinez J, Barbeau K (2001) Reactivity of new selfassembling amphiphilic siderophores and alpha-hydroxy acid-containing siderophores from oceanic bacteria. J Inorg Biochem 86:30

Buyer JS, Delorenzo V, Neilands JB (1991) Production of the siderophore aerobactin by a halophilic pseudomonad. Appl Environ Microbiol 57:2246-2250

Calo D, Kaminski L, Eichler J (2010) Protein glycosylation in Archaea: Sweet and extreme. Glycobiology 20:1065-1076. doi:10.1093/glycob/cwq055

Carpenter C, Payne SM (2014) Regulation of iron transport systems in enterobacteriaceae in response to oxygen and iron availability. J Inorg Biochem 133:110-117. doi:10. 1016/j.jinorgbio.2014.01.007

Christiaen SEA, Matthijs N, Zhang X-H, Nelis HJ, Bossier P, Coenye $T$ (2014) Bacteria that inhibit quorum sensing decrease biofilm formation and virulence in Pseudomonas aeruginosa PAO1. Path Dis 70:271-279. doi:10.1111/ 2049-632x.12124

Cobessi D, Celia H, Pattus F (2005a) Crystal structure at high resolution of ferric-pyochelin and its membrane receptor FptA from Pseudomonas aeruginosa. J Mol Biol 352:893-904. doi:10.1016/j.jmb.2005.08.004

Cobessi D, Celia H, Wirth C, Schalk I, Pattus F (2005b) Structures of iron-siderophore outer membrane receptors from $P$. aeruginosa. Eur Biophys J 34:642

Connell L, Barrett A, Templeton A, Staudigel H (2009) Fungal diversity associated with an active deep sea volcano: vailulu'u seamount, samoa. Geomicrobiol J 26:597-605. doi:10.1080/01490450903316174 
Cornelis P, Matthijs S, Van Oeffelen L (2009) Iron uptake regulation in Pseudomonas aeruginosa. Biometals 22:15-22. doi:10.1007/s10534-008-9193-0

Cotton JL, Tao J, Balibar CJ (2009) Identification and characterization of the staphylococcus aureus gene cluster coding for staphyloferrin A. Biochem 48:1025-1035. doi:10.1021/ bi801844c

Crognale S, Mathe I, Cardone V, Stazi SR, Raduly B (2013) Halobacterial community analysis of Mierlei Saline Lake in Transylvania (Romania). Geomicrobiol J 30:801-812. doi:10.1080/01490451.2013.774073

Crosa JH, Mey AR, Payne SM (2004) Iron transport in bacteria, 1st edn. ASM Press, Washington, DC

Deming JW, Colwell RR (1981) Barophilic Bacteria Associated with Deep-Sea Animals. Bioscience 31:507-511. doi:10. 2307/1308493

Dhungana S et al (2007) Purification and characterization of rhodobactin: a mixed ligand siderophore from Rhodococcus rhodochrous strain OFS. Biometals 20:853-867. doi:10.1007/s10534-006-9079-y

Dimise EJ, Widboom PF, Bruner SD (2008) Structure elucidation and biosynthesis of fuscachelins peptide siderophores from the moderate thermophile Thermobifida fusca. Proc Natl Acad Sci USA 105:15311-15316. doi:10.1073/pnas. 0805451105

Doukyu N, Ogino H (2010) Organic solvent-tolerant enzymes. Biochem Eng J 48:270-282. doi:10.1016/j.bej.2009.09. 009

Drechsel H, Metzger J, Freund S, Jung G, Boelaert JR, Winkelmann G (1991) Rhizoferrin-a novel siderophore from the fungus rhizopus-microsporus var rhizopodiformis. Biol Met 4:238-243. doi:10.1007/bf01141187

Eichler J (2003) Facing extremes: archaeal surface-layer (glyco) proteins. Microbiol 149:3347-3351. doi:10.1099/mic.0. 26591-0

Ejje N, Soe CZ, Gu J, Codd R (2013) The variable hydroxamic acid siderophore metabolome of the marine actinomycete Salinispora tropica CNB-440. Metallomics 5:1519-1528. doi: $10.1039 / \mathrm{c} 3 \mathrm{mt} 00230 \mathrm{f}$

Emmerich M, Bhansali A, Loesekann-Behrens T, Schroeder C, Kappler A, Behrens S (2012) Abundance, distribution, and activity of $\mathrm{Fe}$ (II)-oxidizing and $\mathrm{Fe}$ (iii)-reducing microorganisms in hypersaline sediments of Lake Kasin, Southern Russia. Appl Environ Microbiol 78:4386-4399. doi:10. 1128/aem.07637-11

Fang J, Zhang L, Bazylinski DA (2010) Deep-sea piezosphere and piezophiles: geomicrobiology and biogeochemistry. Trends Microbiol 18:413-422. doi:10.1016/j.tim.2010.06. 006

Ferguson AD, Hofmann E, Coulton JW, Diederichs K, Welte W (1998) Siderophore-mediated iron transport: crystal structure of FhuA with bound lipopolysaccharide. Science 282:2215-2220. doi:10.1126/science.282.5397.2215

Ferguson AD, Braun V, Fiedler HP, Coulton JW, Diederichs K, Welte W (2000) Crystal structure of the antibiotic albomycin in complex with the outer membrane transporter FhuA. Protein Sci 9:956-963

Ferguson AD et al (2001) Active transport of an antibiotic rifamycin derivative by the outer-membrane protein FhuA. Structure 9:707-716. doi:10.1016/s0969-2126(01)00631-1
Ferguson AD, Chakraborty R, Smith BS, Esser L, van der Helm D, Deisenhofer J (2002) Structural basis of gating by the outer membrane transporter FecA. Science 295:1715-1719. doi:10.1126/science.1067313

Figueroa LOS, Schwarz BH, Richards AM (2012) Characterization of New Siderophores Produced by a Soda Lake Isolate. Abstr Gen Meet Amer Soc Microbiol 112:404

Figueroa LOS, Schwarz B, Richards AM (2015) Structural characterization of amphiphilic siderophores produced by a soda lake isolate, Halomonas sp SL01, reveals cysteine-, phenylalanine- and proline-containing head groups. Extremophiles 19:1183-1192. doi:10.1007/s00792-0150790-x

Fineran PC, Slater H, Everson L, Hughes K, Salmond GPC (2005) Biosynthesis of tripyrrole and beta-lactam secondary metabolites in Serratia: integration of quorum sensing with multiple new regulatory components in the control of prodigiosin and carbapenem antibiotic production. Mol Microbiol 56:1495-1517. doi:10.1111/j.13652958.2005.04660.x

Fisher CR, Davies NMLL, Wyckoff EE, Feng Z, Oaks EV, Payne SM (2009) Genetics and virulence association of the shigella flexneri sit iron transport system. Infect Immun 77:1992-1999. doi:10.1128/iai.00064-09

Fleming EJ, Davis RE, McAllister SM, Chan CS, Moyer CL, Tebo BM, Emerson D (2013) Hidden in plain sight: discovery of sheath-forming, iron-oxidizing Zetaproteobacteria at Loihi Seamount, Hawaii, USA. FEMS Microbiol Ecol 85:116-127. doi:10.1111/1574-6941.12104

Friedmann EI, Ocampo R (1976) Endolithic blue-green-algae in dry valleys-primary producers in Antarctic desert ecosystem. Science 193:1247-1249. doi:10.1126/science. 193.4259.1247

Friedmann EI, McKay CP, Nienow JA (1987) The cryptoendolithic microbial environment in the Ross Desert of Antarcticasatellite-transmitted continuos nanoclimate data, 1984 to 1986. Polar Biol 7:273-287. doi:10.1007/bf00443945

Fujita MJ, Sakai R (2014) Production of avaroferrin and putrebactin by heterologous expression of a deep-sea metagenomic DNA. Mar Drugs 12:4799-4809. doi:10. 3390/md12094799

Gascoyne DJ, Connor JA, Bull AT (1991a) Capacity of siderophore-producing alkalophilic bacteria to accumulate iron, gallium and aluminum. Appl Microbiol Biotechnol 36:136-141

Gascoyne DJ, Connor JA, Bull AT (1991b) Isolation of bacteria producing siderophores under alkaline conditions. Appl Microbiol Biotechnol 36:130-135

Gauglitz J, Butler A (2013) Amino acid variability in the peptide composition of a suite of amphiphilic peptide siderophores from an open ocean Vibrio species. J Biol Inorg Chem 18:489-497. doi:10.1007/s00775-013-0995-3

Gauglitz JM, Zhou HJ, Butler A (2012) A suite of citratederived siderophores from a marine Vibrio species isolated following the Deepwater Horizon oil spill. J Inor Biochem 107:90-95. doi:10.1016/j.jinorgbio.2011.10.013

Gehring AM, Bradley KA, Walsh CT (1997) Enterobactin biosynthesis in Escherichia coli: isochorismate lyase (EntB) is a bifunctional enzyme that is phosphopantetheinylated by EntD and then acylated by EntE using ATP 
and 2,3-dihydroxybenzoate. Biochem 36:8495-8503. doi:10.1021/bi970453p

Georlette D, Damien B, Blaise V, Depiereux E, Uversky VN, Gerday C, Feller G (2003) Structural and functional adaptations to extreme temperatures in psychrophilic, mesophilic, and thermophilic DNA ligases. J Biol Chem 278:37015-37023. doi:10.1074/jbc.M305142200

Ghozlan H, Deif H, Abu Kandil R, Sabry S (2006) Biodiversity of moderately halophilic bacteria in hypersaline habitats in Egypt. J Gen Appl Microbiol 52:63-72. doi:10.2323/jgam. 52.63

Gledhill M, McCormack P, Ussher S, Achterberg E, Mantoura R, Worsfold P (2004) Production of siderophore type chelates by mixed bacterioplankton populations in nutrient enriched seawater incubations. Mar Chem 88:75-83. doi:10.1016/j.marchem.2004.03.003

Goswami D, Dhandhukia P, Patel P, Thakker JN (2014a) Screening of PGPR from saline desert of Kutch: growth promotion in Arachis hypogea by Bacillus licheniformis A2. Microbiol Res 169:66-75. doi:10.1016/j.micres.2013. 07.004

Goswami D, Pithwa S, Dhandhukia P, Thakker JN (2014b) Delineating kocuria turfanensis $2 \mathrm{M} 4$ as a credible PGPR: a novel IAA-producing bacteria isolated from saline desert. J Plant Interact 9:566-576. doi:10.1080/17429145.2013. 871650

Gounder K et al (2011) Sequence of the hyperplastic genome of the naturally competent thermus scotoductus SA-01. BMC Genom 12:14. doi:10.1186/1471-2164-12-577

Guerry P, PerezCasal J, Yao RJ, McVeigh A, Trust TJ (1997) A genetic locus involved in iron utilization unique to some Campylobacter strains. J Bacteriol 179:3997-4002

Handley KM, Lloyd JR (2013) Biogeochemical implications of the ubiquitous colonization of marine habitats and redox gradients by Marinobacter species. Front Microbiol 4:10. doi:10.3389/fmicb.2013.00136

Hantke K (1987) Ferrous iron transport mutants in escherichiacoli-K12. FEMS Microbiol Lett 44:53-57. doi:10.1111/j. 1574-6968.1987.tb02241.x

Hantke K (2004) Ferrous iron transport. In: Crosa JH, Mey AR, Payne SM (eds) Iron transport in bacteria, vol 1. ASM Press, Washington, DC, pp 178-184

Harris W, Amin S, Kupper F, Green D, Carrano C (2007) Borate binding to siderophores: Structure and stability. J Am Chem Soc 129:12263-12271. doi:10.1021/ja073788v

Hedlund BP, Dodsworth JA, Cole JK, Panosyan HH (2013) An integrated study reveals diverse methanogens, Thaumarchaeota, and yet-uncultivated archaeal lineages in Armenian hot springs Anton Van Leeuwenhoek. Anton Leeuw Int J G 104:71-82. doi:10.1007/s10482013-9927-z

Homann V, Sandy M, Tincu J, Templeton A, Tebo B, Butler A (2009) Loihichelins A-F, a suite of amphiphilic siderophores produced by the marine bacterium halomonas LOB-5. J Nat Prod 72:884-888. doi:10.1021/np800640h

Hopkinson B, Morel F (2009) The role of siderophores in iron acquisition by photosynthetic marine microorganisms. Biometals 22:659-669. doi:10.1007/s10534-009-9235-2

Horowitz NH, Hubbard JS, Cameron RE (1972) Microbiology of dry Valleys of Antarctica. Science 176:242. doi:10. $1126 /$ science.176.4032.242
Huidrom P, Rajkumar B, Sharma GD (2011) Screening of native bacteria isolated from tea garden soil of South Assam for their abiotic stress tolerance. J Pure Appl Microbiol 5:349-353

Ito Y, Butler A (2005) Structure of synechobactins, new siderophores of the marine cyanobacterium Synechococcus $\mathrm{sp}$ PCC 7002. Limnol Oceanogr 50:1918-1923

Jarrell KF et al. (2011) Archaeal surface appendages: their function and the critical role of N-linked glycosylation in their assembly. In: Conference on instruments, methods, and missions for astrobiology XIV, SPIE, San Diego, CA, Aug 23-25 2011. doi:81520o10.1117/12.892939

Jorgensen SL, Thorseth IH, Pedersen RB, Baumberger T, Schleper C (2013) Quantitative and phylogenetic study of the Deep Sea Archaeal Group in sediments of the Arctic midocean spreading ridge. Front Microbiol 4:299. doi:10. 3389/fmicb.2013.00299

Kadirvel M, Fanimarvasti F, Forbes S, McBain A, Gardiner JM, Brown GD, Freeman S (2014) Inhibition of quorum sensing and biofilm formation in Vibrio harveyi by 4-fluoroDPD: a novel potent inhibitor of Al-2 signalling. Chem Commun 50:5000-5002. doi:10.1039/c3cc49678c

Kalinowski BE, Johnsson A, Arlinger J, Pedersen K, OdeggrdJensen A, Edberg F (2006) Microbial mobilization of uranium from shale mine waste. Geomicrobiol $\mathbf{J}$ 23:157-164. doi:10.1080/01490450600599197

Karagoz K, Ates F, Karagoz H, Kotan R, Cakmakci R (2012) Characterization of plant growth-promoting traits of bacteria isolated from the rhizosphere of grapevine grown in alkaline and acidic soils. Eur J Soil Biol 50:144-150. doi:10.1016/j.ejsobi.2012.01.007

Kaye J, Sylvan J, Edwards K, Baross J (2011) Halomonas and Marinobacter ecotypes from hydrothermal vent, subseafloor and deep-sea environments. FEMS Microbiol Ecol 75:123-133. doi:10.1111/j.1574-6941.2010.00984.x

Kodani S et al (2013) Structure and biosynthesis of scabichelin, a novel tris-hydroxamate siderophore produced by the plant pathogen Streptomyces scabies 87.22. Org Biomol Chem 11:4686-4694. doi:10.1039/c3ob40536b

Kogej T, Gorbushina AA, Gunde-Cimerman N (2006) Hypersaline conditions induce changes in cell-wall melanization and colony structure in a halophilic and a xerophilic black yeast species of the genus Trimmatostroma. Mycol Res 110:713-724. doi:10.1016/j.mycres.2006.01.014

Konetschny-Rapp S, Jung G, Raymond KN, Meiwes J, Zahner H (1992) Solution Thermodynamics of the Ferric Complexes of New Desferrioxamine Siderophores Obtained by Directed Fermentation. J Am Chem Soc 114:2224-2230. doi:10.1021/ja00032a043

Kozubal MA et al (2013) Geoarchaeota: a new candidate phylum in the Archaea from high-temperature acidic iron mats in Yellowstone National Park. ISME J 7:622-634. doi:10. 1038/ismej.2012.132

Krewulak KD, Vogel HJ (2008) Structural biology of bacterial iron uptake. Biochim Biophys Acta 1778:1781-1804. doi:10.1016/j.bbamem.2007.07.026

Kube M et al (2013) Genome sequence and functional genomic analysis of the oil-degrading bacterium Oleispira Antarctica. Nature Commun 4:11. doi:10.1038/ncomms3156

Kusel K, Dorsch T, Acker G, Stackebrandt E (1999) Microbial reduction of $\mathrm{Fe}(\mathrm{III})$ in acidic sediments: isolation of 
Acidiphilium cryptum JF-5 capable of coupling the reduction of $\mathrm{Fe}(\mathrm{III})$ to the oxidation of glucose. Appl Environ Microbiol 65:3633-3640

Lewenza S, Conway B, Greenberg EP, Sokol PA (1999) Quorum sensing in Burkholderia cepacia: identification of the LuxRI homologs CepRI. J Bacteriol 181:748-756

Li XY, Hu Y, Gong J, Zhang LS, Wang GJ (2013) Comparative genome characterization of Achromobacter members reveals potential genetic determinants facilitating the adaptation to a pathogenic lifestyle. Appl Microbiol Biotechnol 97:6413-6425. doi:10.1007/s00253-013-5018-3

Liu SV, Zhou JZ, Zhang CL, Cole DR, GajdarziskaJosifovska M, Phelps TJ (1997) Thermophilic Fe(III)-reducing bacteria from the deep subsurface: the evolutionary implications. Science 277:1106-1109. doi:10.1126/science.277. 5329.1106

Liu N, Shang F, Xi LJ, Huang Y (2013) Tetroazolemycins A and B, two new oxazole-thiazole siderophores from deep-sea streptomyces olivaceus FXJ8.012. Mar Drugs 11:1524-1533. doi:10.3390/md11051524

Lorenzo Vd, Perez-Martin J, Escolar L, Pesole G, Bertoni G (2004) Mode of binding of the fur protein to target DNA: negative regulation of iron-controlled gene expression. In: Crosa JH, Mey AR, Payne SM (eds) Iron transport in bacteria, vol 1. ASM Press, Washington, DC, pp 185-196

Luo XZ, Wu SX, Liang YQ (2002) Vesicle formation induced by metal ions from micelle-forming sodium hexadecylimino diacetate in dilute aqueous. Chem Commun 5:492-493. doi:10.1039/b110797f

Luque-Almagro VM, Blasco R, Huertas MJ, Martinez-Luque M, Moreno-Vivian C, Castillo F, Roldan MD (2005a) Alkaline cyanide biodegradation by Pseudomonas pseudoalcaligenes CECT5344. Biochem Soc Transact 33:168-169

Luque-Almagro VM et al (2005b) Bacterial degradation of cyanide and its metal complexes under alkaline conditions. Appl Environ Microbiol 71:940-947. doi:10.1128/aem.71. 2.940-947.2005

Luque-Almagro VM, Blasco R, Martinez-Luque M, MorenoVivian C, Castillo F, Roldan MD (2011) Bacterial cyanide degradation is under review: Pseudomonas pseudoalcaligenes CECT5344, a case of an alkaliphilic cyanotroph. Biochem Soc Trans 39:269-274. doi:10.1042/ bst0390269

Luther GW, Wu JF (1997) What controls dissolved iron concentrations in the world ocean? A comment. Mar Chem 57:173-179. doi:10.1016/s0304-4203(97)00046-7

Machuca A, Aoyama H, Duran N (1999) Isolation and partial characterization of an extracellular low-molecular mass component with high phenoloxidase activity from Thermoascus aurantiacus. Biochem Biophys Res Commun 256:20-26. doi:10.1006/bbrc.1998.9927

Malviya N, Yandigeri MS, Yadav AK, Solanki MK, Arora DK (2014) Isolation and characterization of novel alkalihalophilic actinomycetes from the Chilika brackish water lake. India Ann Microbiol 64:1829-1838. doi:10.1007/ s13213-014-0831-1

Martin J, Ito Y, Homann V, Haygood M, Butler A (2006) Structure and membrane affinity of new amphiphilic siderophores produced by Ochrobactrum sp SP18. J Biol Inorg Chem 11:633-641. doi:10.1007/s00775-006-0112-y
Martinez J, Butler A (2007) Marine amphiphilic siderophores: marinobactin structure, uptake, and microbial partitioning. J Inorg Biochem 101:1692-1698. doi:10.1016/j.jinorgbio. 2007.07.007

Martinez J, Zhang G, Holt P, Jung H, Carrano C, Haygood M, Butler A (2000) Self-assembling amphiphilic siderophores from marine bacteria. Science 287:1245-1247. doi:10. 1126/science.287.5456.1245

Martinez JS, Haygood MG, Butler A (2001) Identification of a natural desferrioxamine siderophore produced by a marine bacterium. Limnol Oceanogr 46:420-424

Martinez J, Carter-Franklin J, Mann E, Martin J, Haygood M, Butler A (2003) Structure and membrane affinity of a suite of amphiphilic siderophores produced by a marine bacterium. Proc Natl Acad Sci USA 100:3754-3759. doi:10. 1073/pnas.0637444100

McMillan DGG et al (2010) Acquisition of iron by alkaliphilic bacillus species. Appl Environ Microbiol 76:6955-6961. doi:10.1128/aem.01393-10

Meiwes J, Fiedler HP, Haag H, Zahner H, Konetschny-Rapp S, Jung G (1990) Isolation and characterization of staphyloferrin A, a compound with siderophore activity from Staphylococcus hyicus DSM 20459. FEMS Microbiol Lett 55:201-205

Mishra PK, Mishra S, Selvakumar G, Bisht SC, Bisht JK, Kundu S, Gupta HS (2008) Characterisation of a psychrotolerant plant growth promoting Pseudomonas sp strain PGERs17 (MTCC 9000) isolated from North Western Indian Himalayas. Ann Microbiol 58:561-568

Neilands JB (1995) Siderophores-structure and function of microbial iron transport compounds. J Biol Chem 270:26723-26726

Nogi Y, Kato C, Horikoshi K (1998) Moritella japonica sp. nov., a novel barophilic bacterium isolated from a Japan Trench sediment. J Gen Appl Microbiol 44:289-295. doi:10.2323/ jgam.44.289

Olsson-Francis K, de la Torre R, Cockell CS (2010) Isolation of Novel Extreme-Tolerant Cyanobacteria from a RockDwelling Microbial Community by Using Exposure to Low Earth Orbit. Appl Environ Microbiol 76:2115-2121. doi:10.1128/aem.02547-09

Osorio H, Martinez V, Nieto PA, Holmes DS, Quatrini R (2008) Microbial iron management mechanisms in extremely acidic environments: comparative genomics evidence for diversity and versatility. BMC Microbiol 8:1. doi:10.1186/ 1471-2180-8-203

Owen T, Pynn R, Martinez J, Butler A (2005) Micelle-to-vesicle transition of an iron-chelating microbial surfactant, marinobactin E. Langmuir 21:12109-12114. doi:10.1021/ la0519352

Owen T, Pynn R, Hammouda B, Butler A (2007) Metal-dependent self-assembly of a microbial surfactant. Langmuir 23:9393-9400. doi:10.1021/la700671p

Owen T, Webb S, Butler A (2008) XAS study of a metal-induced phase transition by a microbial surfactant. Langmuir 24:4999-5002. doi:10.1021/la703833v

Packiavathy IASV, Sasikumar P, Pandian SK, Veera Ravi A (2013) Prevention of quorum-sensing-mediated biofilm development and virulence factors production in Vibrio spp. by curcumin. Appl Microbiol Biotechnol 97:10177-10187. doi:10.1007/s00253-013-4704-5 
Pan HQ, Hu JC (2015) Draft genome sequence of the novel strain Pseudomonas sp 10B238 with potential ability to produce antibiotics from deep-sea sediment. Mar Genom 23:55-57. doi:10.1016/j.margen.2015.05.003

Pandit AS et al (2015) A snapshot of microbial communities from the Kutch: one of the largest salt deserts in the World. Extremophiles 19:973-987. doi:10.1007/s00792-0150772-z

Pettit RK (2011) Culturability and secondary metabolite diversity of extreme microbes: expanding contribution of deep sea and deep-sea vent microbes to natural product discovery. Mar Biotechnol 13:1-11. doi:10.1007/s10126-010-9294-y

Picard A, Testemale D, Wagenknecht L, Hazael R, Daniel I (2014) Iron reduction by the deep-sea bacterium Shewanella profunda LT13a under subsurface pressure and temperature conditions. Front Microbiol 5:796. doi:10. 3389/fmicb.2014.00796

Pick U (2004) The respiratory inhibitor antimycin A specifically binds $\mathrm{Fe}$ (III) ions and mediates utilization of iron by the halotolerant alga Dunaliella salina (Chlorophyta). Biometals 17:79-86. doi:10.1023/a:1024480720962

Potrykus J, Jonna VR, Dopson M (2011) Iron homeostasis and responses to iron limitation in extreme acidophiles from the Ferroplasma genus. Proteomics 11:52-63. doi:10.1002/ pmic. 201000193

Quatrini R, Lefimil C, Holmes DS, Jedlicki E (2005) The ferric iron uptake regulator (Fur) from the extreme acidophile Acidithiobacillus ferrooxidans. Microbiol 151:2005-2015. doi: $10.1099 / \mathrm{mic} .0 .27581-0$

Quatrini R, Lefimil C, Veloso FA, Pedroso I, Holmes DS, Jedlicki E (2007) Bioinformatic prediction and experimental verification of Fur-regulated genes in the extreme acidophile Acidithiobacillus ferrooxidans. Nucleic Acids Res 35:2153-2166. doi:10.1093/nar/gkm068

Raina S, De Vizio D, Palonen EK, Odell M, Brandt AM, Soini JT, Keshavarz T (2012) Is quorum sensing involved in lovastatin production in the filamentous fungus Aspergillus terreus? Process Biochem 47:843-852. doi:10.1016/j. procbio.2012.02.021

Ramadoss D, Lakkineni VK, Bose P, Ali S, Annapurna K (2013) Mitigation of salt stress in wheat seedlings by halotolerant bacteria isolated from saline habitats. Springer Plus 2:7. doi:10.1186/2193-1801-2-6

Ren GM, Jin Y, Zhang CM, Gu HD, Qu JJ (2015) Characteristics of Bacillus sp PZ-1 and its biosorption to $\mathrm{Pb}(\mathrm{II})$. Ecotoxicol Environ Saf 117:141-148. doi:10.1016/j. ecoenv.2015.03.033

Richards AM, Peyton BM, Apel WA (2006) Characterization of siderophores produced by halophilic microorganisms isolated from Soap Lake in Washington State. Abstr Gen Meet Am Soc Microbiol 106:387

Richards AM, Peyton BM, Gerlach R, Apell WA (2007) Characterization of siderophores produced by halo-alkaliphiles isolated from terrestrial environments. Abstr Gen Meet Am Soc Microbiol 107:565

Rossello-Mora RA et al (1995) Isolation and taxonomic characterization of a halotolerant, facultatively iron-reducing bacterium system. Appl Microbiol 17:569-573

Sahay H, Mahfooz S, Singh AK, Singh S, Kaushik R, Saxena AK, Arora DK (2012) Exploration and characterization of agriculturally and industrially important haloalkaliphilic bacteria from environmental samples of hypersaline Sambhar lake, India. World J Microbiol Biotechnol 28:3207-3217. doi:10.1007/s11274-012-1131-1

Sandy M, Butler A (2009) Microbial iron acquisition: marine and terrestrial siderophores. Chem Rev 109:4580-4595. doi:10.1021/cr9002787

Sarethy IP, Saxena Y, Kapoor A, Sharma M, Sharma SK, Gupta V, Gupta S (2011) Alkaliphilic bacteria: applications in industrial biotechnology. J Ind Microbiol Biotechnol 38:769-790. doi:10.1007/s10295-011-0968-x

Sarkar A, Kazy SK, Sar P (2013) Characterization of arsenic resistant bacteria from arsenic rich groundwater of West Bengal, India. Ecotoxicology 22:363-376. doi:10.1007/ s10646-012-1031-z

Scandurra R, Consalvi V, Chiaraluce R, Politi L, Engel PC (1998) Protein thermostability in extremophiles. Biochimie 80:933-941. doi:10.1016/s0300-9084(00)88890-2

Serrano Figueroa LO (2015) A study on amphiphilic siderophore detection, structure elucidation and their ironmediated vesicle self-assembly. Montana State University, Bozeman

Seyedsayamdost MR, Traxler MF, Zheng S-L, Kolter R, Clardy J (2011) Structure and biosynthesis of amychelin an unusual mixed-ligand siderophore from Amycolatopsis sp. AA4. J Am Chem Soc 133:11434-11437. doi:10.1021/ ja203577e

Siebert J, Hirsch P, Hoffmann B, Gliesche CG, Peissl K, Jendrach M (1996) Cryptoendolithic microorganisms from Antarctic sandstone of linnaeus terrace (Asgard range): diversity, properties and interactions. Biodiver Conserv 5:1337-1363. doi:10.1007/bf00051982

Soe CZ, Codd R (2014) Unsaturated macrocyclic dihydroxamic acid siderophores produced by shewanella putrefaciens using precursor-directed biosynthesis. ACS Chem Biol 9:945-956. doi:10.1021/cb400901j

Stintzi A, Evans K, Meyer JM, Poole K (1998) Quorum-sensing and siderophore biosynthesis in Pseudomonas aeruginosa: lasR/lasI mutants exhibit reduced pyoverdine biosynthesis. FEMS Microbiol Lett 166:341-345. doi:10.1111/j.15746968.1998.tb13910.x

Sudek LA, Templeton AS, Tebo BM, Staudigel H (2009) Microbial ecology of Fe (hydr)oxide mats and Basaltic rock from Vailulu'u seamount, American Samoa. Geomicrobiol J 26:581-596. doi:10.1080/01490450903263400

Sunagawa $S$ et al (2015) Structure and function of the global ocean microbiome. Science 348:1261359. doi:10.1126/ science. 1261359

Tal-Gan Y, Stacy DM, Foegen MK, Koenig DW, Blackwell HE (2013) Highly potent inhibitors of quorum sensing in staphylococcus aureus revealed through a systematic synthetic study of the group-iii autoinducing peptide. J Am Chem Soc 135:7869-7882. doi:10.1021/ja3112115

Tang YJ et al (2009) Analysis of metabolic pathways and fluxes in a newly discovered thermophilic and ethanol-tolerant geobacillus strain. Biotechnol Bioeng 102:1377-1386. doi:10.1002/bit.22181

Temirov YV, Esikova TZ, Kashparov IA, Balashova TA, Vinokurov LM, Alakhov YB (2003) A catecholic siderophore produced by the thermoresistant Bacillus licheniformis VK21 strain. Russ J Bioorg Chem 29:542-549. doi:10.1023/B:RUBI.0000008894.80972.2e 
Tipre S, Pindi PK, Sharma S (2015) Biotechnological potential of a Halobacterium of family Bacillaceae Indian. J Biotechnol 14:65-71

Tsolis RM, Baumler AJ, Heffron F, Stojiljkovic I (1996) Contribution of TonB- and Feo-mediated iron uptake to growth of Salmonella typhimurium in the mouse. Infect Immun 64:4549-4556

Vasavi HS, Arun AB, Rekha P-D (2014) Anti-quorum sensing activity of Psidium guajava L. flavonoids against Chromobacterium violaceum and Pseudomonas aeruginosa PAO1. Microbiol Immunol 58:286-293. doi:10.1111/ 1348-0421.12150

Verma R, Naosekpam AS, Kumar S, Prasad R, Shanmugam V (2007) Influence of soil reaction on diversity and antifungal activity of fluorescent pseudomonads in crop rhizospheres. Bioresour Technol 98:1346-1352. doi:10.1016/j.biortech. 2006.05.030

Vishal VK, Manuel VBR (2015) Effect of ACC-deaminase producing Bacillus cereus brm on the growth of Vigna radiata (Mung beans) under salinity stress. Res J Biotechnol 10:122-130

Vraspir JM, Holt PD, Butler A (2011) Identification of new members within suites of amphiphilic marine siderophores. Biometals 24:85-92. doi:10.1007/s10534-010-9378-1

Wang F et al (2008) Environmental adaptation: genomic analysis of the piezotolerant and psychrotolerant deep-sea iron reducing bacterium shewanella piezotolerans WP3. PLoS One 3:e1937. doi:10.1371/journal.pone.0001937

Weaver EA, Wyckoff EE, Mey AR, Morrison R, Payne SM (2013) FeoA and FeoC are essential components of the vibrio cholerae ferrous iron uptake system, and FeoC interacts with FeoB. J Bacteriol 195:4826-4835. doi:10. 1128/jb.00738-13

Wilhelm SW, MacAuley K, Trick CG (1998) Evidence for the importance of catechol-type siderophores in the iron-limited growth of a cyanobacterium. Limnol Oceanogr 43:992-997

Wirsen CO, Molyneaux SJ (1999) A study of deep-sea natural microbial populations and barophilic pure cultures using a high-pressure chemostat. Appl Environ Microbiol 65:5314-5321

Woo S-M, Kim S-D (2008) Structural identification of siderophore(AH18) from bacillus subtilis AH18, a biocontrol agent of phytophthora blight disease in red-pepper Korean. J Microbiol Biotechnol 36:326-335

Wood AP, Kelly DP (1991) Isolation and characterization of thiobacillus-halophilus Sp-nov, A sulfur-oxidizing autotrophic eubacterium from a Western Australian Hypersaline Lake. Arch Microbiol 156:277-280. doi:10.1007/ bf00262998

Wu LL, Brucker RP, Beard BL, Roden EE, Johnson CM (2013a) Iron isotope characteristics of hot springs at chocolate pots, Yellowstone National Park. Astrobiology 13:1091-1101. doi:10.1089/ast.2013.0996

Wu WF, Wang FP, Li JH, Yang XW, Xiao X, Pan YX (2013b) Iron reduction and mineralization of deep-sea iron reducing bacterium Shewanella piezotolerans WP3 at elevated hydrostatic pressures. Geobiology 11:593-601. doi:10.1111/gbi.12061

Xu G, Martinez J, Groves J, Butler A (2002) Membrane affinity of the amphiphilic marinobactin siderophores. J Am Chem Soc 124:13408-13415. doi:10.1021/ja026768w

Yadav S, Kaushik R, Saxena AK, Arora DK (2011) Diversity and phylogeny of plant growth-promoting bacilli from moderately acidic soil. J Basic Microbiol 51:98-106. doi:10.1002/jobm.201000098

Yadav AN, Sachan SG, Verma P, Saxena AK (2015a) Prospecting cold deserts of north western Himalayas for microbial diversity and plant growth promoting attributes. J Biosci Bioeng 119:683-693. doi:10.1016/j.jbiosc.2014. 11.006

Yadav AN, Sachan SG, Verma P, Tyagi SP, Kaushik R, Saxena AK (2015b) Culturable diversity and functional annotation of psychrotrophic bacteria from cold desert of Leh Ladakh (India). World J Microbiol Biotechnol 31:95-108. doi:10. 1007/s11274-014-1768-Z

Ye Q, Roh Y, Carroll SL, Blair B, Zhou JZ, Zhang CL, Fields MW (2004) Alkaline anaerobic respiration: isolation and characterization of a novel alkaliphilic and metal-reducing bacterium. Appl Environ Microbiol 70:5595-5602. doi:10. 1128/aem.70.9.5595-5602.2004

Yue WW, Grizot S, Buchanan SK (2003) Structural evidence for iron-free citrate and ferric citrate binding to the TonBdependent outer membrane transporter FecA. J Mol Biol 332:353-368. doi:10.1016/s0022-2836(03)00855-6

Zane HK, Butler A (2013) Isolation, structure elucidation, and iron-binding properties of lystabactins, siderophores isolated from a marine Pseudoalteromonas sp. J Nat Prod 76:648-654. doi:10.1021/np3008655

Zane HK, Naka H, Rosconi F, Sandy M, Haygood MG, Butler A (2014) Biosynthesis of amphi-enterobactin siderophores by Vibrio harveyi BAA-1116: identification of a bifunctional nonribosomal peptide synthetase condensation domain. J Am Chem Soc 136:5615-5618. doi:10.1021/ ja5019942

Zhang CL, Stapleton RD, Zhou JZ, Palumbo AV, Phelps TJ (1999) Iron reduction by psychotrophic enrichment cultures. FEMS Microbiol Ecol 30:367-371. doi:10.1111/j. 1574-6941.1999.tb00664.x

Zhang J, Dong HL, Liu D, Agrawal A (2013) Microbial reduction of $\mathrm{Fe}(\mathrm{III})$ in smectite minerals by thermophilic methanogen Methanothermobacter thermautotrophicus. Geochim Cosmochim Acta 106:203-215. doi:10.1016/j. gca.2012.12.031

Zhou J, Liu S, Xia B, Zhang C, Palumbo AV, Phelps TJ (2001) Molecular characterization and diversity of thermophilic iron-reducing enrichment cultures from deep subsurface environments. J Appl Microbiol 90:96-105. doi:10.1046/j. 1365-2672.2001.01192.x

Zobell CE, Morita RY (1957) Barophilic bacteria in some deep sea sediments. J Bacteriol 73:563-568 